(c) Saudi Society for Geosciences 2012

The original publication is available at http://www.springerlink.com

\title{
The Cryogenian arc formation and successive high-K calc-alkaline plutons of Socotra Island (Yemen)
}

\author{
Y. Denèle ${ }^{1,2, a,{ }^{*}}$, S. Leroy ${ }^{1}$, E. Pelleter ${ }^{3}$, R. Pik ${ }^{4}$, J-Y. Talbot ${ }^{5}$, K. Khanbari ${ }^{6}$
}

${ }^{1}$ UPMC Univ Paris 06, UMR 7193, ISTEP, 75005 Paris, France

${ }^{2}$ Géosciences Montpellier, UMR CNRS 5243, Université Montpellier II, Place Bataillon, 34095 Montpellier, France

${ }^{3}$ IFREMER, Centre de Brest, BP70, 29280 Plouzané, France

${ }_{5}^{4}$ CRPG, Nancy-Université CNRS, 54501 Vandoeuvre-lès-Nancy, France

${ }^{5}$ CREGU, 54501 Vandoeuvre-lès-Nancy, France

${ }^{6}$ Geological Survey, Sanaa, Republic of Yemen

${ }^{\text {a }}$ Present address : GET, Université de Toulouse-CNRS-IRD-OMP, 14 Avenue E. Belin, 31400 Toulouse, France

*: Corresponding author : Yoann Denèle, email address : yoann.denele@get.obs-mip.fr

\begin{abstract}
:
The Socotra Island belongs to the southern rifted margin of the Gulf of Aden and occupied in Neoproterozoic times a key position to constrain the age and the nature of the largely hidden Neoproterozoic rocks of the Arabian plate. Our integrated field, petrographic, geochemical and geochronological study in the Neoproterozoic rocks recognises three main successive events: (a) hightemperature ductile deformation and metamorphism forming probably in a compressive or transpressive regime; (b) mafic to intermediate intrusions as vertical sheets, kilometre-scale gabbro laccoliths, mafic dike swarm and lavas which present mainly a depleted arc signature with some evidences of evolution from an enriched-arc signature; (c) felsic intrusions mainly composed of highly potassic calc-alkaline and pinkish granites dated between 840 and $780 \mathrm{Ma}$. Relationships between the various petrographic types and $\mathrm{U}-\mathrm{Pb}$ data suggest that these events occurred during a relatively short time span (80 $\mathrm{Ma}$ at max). Earlier high-temperature-low-pressure metamorphism stage as well as geochemical signature of mafic rocks show that development of Cryogenian formations of Socotra were controlled successively by an Andean-arc and a back-arc setting. These features cannot be easily reconciled with those of the Arabian-Nubian shield to the west of Socotra and of the Mozambique Belt to the south. We propose that the Socotra basement was developed at an active margin close to the India block in Cryogenian times.
\end{abstract}

Keywords : Neoproterozoic ; East African-Antartic Orogen ; Arabian-Nubian shield ; Socotra Island ; Andean-type arc ; Back-arc basin 


\section{Introduction}

The East-African-Antartic-Orogen (EAAO, Fig. 1a), one of the hugest orogen of the Earth history, extends over 8000 kilometres from Egypt to the north to Antarctica to the south (Stern, 1994; Meert, 2003; Jacobs and Thomas, 2004, 2010). The EAAO corresponds to a N52 S Neoproterozoic collision zone between proto-East Gondwana represented by the current Arabia, Somalia, Pakistan, India and Madagascar and the proto-West Gondwana represented by the East-Saharian, Congo and Tanzania cratons (Meert, 2003; Collins and Pisarevsky, 2005; Collins, 2006). This orogen presents a great complexity due to the fact that East and West Gondwana did not exist as Neoproterozoic supercontinents in their own right, but correspond to an accretion of various terranes which gathered during the Neoproterozoic time (see Collins and Pisarevsky, 2005, and references therein). The northern part of the EAAO corresponds to the Arabian-Nubian shield (ANS, Fig. 1b) dominated by juvenile mid-Neoproterozoic (Cryogenian) island-arc terranes associated to microcontinental blocks such as the AfifAbbas composite terrane and the Al Mahfid gneiss terrane (e.g. Stern, 1994; Whitehouse et al., 1998 and 2001; Johnson and Woldehaimot, 2003, Meert, 2003; Collins and Pisarevsky, 2005), both bounded by sutures zones with ophiolites. ANS is characterized by mild accretion at low to medium metamorphic grade (Stern, 1994; Shackleton, 1996) which occurred between 700 and 600 Ma (Nehlig et al., 2002, references therein), and by a final stage of post-orogenic extension marked by late calc-alkaline and alkaline igneous activity and by formation of some core complexes (Blasband et al., 2000; Greiling et al., 1994; Avigad and Gvirtzman, 2009) which began around $600 \mathrm{Ma}$ (Jonhson and Woldehaimot, 2003). By contrast the southern part of the EAAO shows high-grade rocks 
of Ediacaran-early Cambrian age and is devoid of accreted juvenile Neoproterozoic arc formations (Jacobs and Thomas, 2004, Bingen et al., 2009). This part of the orogen seems to represent a continent-continent collision zone which occurred during the final accretion of various Gondwana blocks (Muhlongo and Lenoir, 1994; Jacobs et al., 1998; Kröner et al., 2001, Jacobs and Thomas, 2004).

There is a lack of magnetic data for the period between $1 \mathrm{Ga}$ to $820 \mathrm{Ma}$ to identify clearly the eastern limit of the EAOO and of the composites terranes of the ANS (Li et al., 2008). For instance, new models of late Mesoprotezoic reconstruction proposed that the ANS microcontinental blocks were either placed adjacent to northeast India (e.g. Li and Powell, 2001), adjacent and outboard of the Congo-São Francisco cratons (Collins and Pisarevsky, 2005), or between India and Sahara (Li et al., 2008). The Socotra Island (Yemen, Fig. 1b) have occupied, prior to the Oligo-Miocene Gulf of Aden opening (e.g. d'Acremont et al., 2006; Leroy et al., 2010a), a key position between the proto-East Gondwana, the high-grade rocks of the EAAO and the ANS (Fig. 1a). It corresponds, together with the basement of Mirbat in Oman, to the only km-scale outcrop of Neoproterozic rocks in the eastern part of the Arabic plate (Fig. 1b). In this way, the study of the Socotra Neoproterozoic rocks should allow the specification of the boundaries of the various domains of the EAAO and their geological histories. We investigate the Neoproterozoic basement of Socotra and propose, based on an integrated field, petrographic, geochemical and geochronological study, that it corresponds to a well-preserved Cryogenian arc that may have formed above an active margin of the Indian proto East-Gondwana block.

\section{Geological setting}

The Socotra Island belongs to the southern rifted margin of the Gulf of Aden which is an active oceanic basin (Leroy et al., 2004). The Gulf of Aden forms by the split away of Somalia plate to the South and Arabian plate to the North resulting from an oblique rifting characterized by a $\mathrm{N} 20^{\circ} \mathrm{E}$-striking extension and a $\mathrm{N} 70^{\circ} \mathrm{E}$-oriented rift (Bellahsen et al., 2006; Autin et al., 2010). Rifting history started around $35 \mathrm{Ma}$ and oceanic accretion is recorded since 17.6 Ma along the whole Gulf of Aden, sensu stricto (e.g. Leroy et al., 2010a and b; Leroy et al., this volume).

The Gulf of Aden rifting is expressed in two different ways in the Socotra Island: a western domain made up of two well-expressed Oligo-Miocene tilted blocks (Razin et al., 
2010; Fig. 2) and an eastern domain composed of a single and huge tilted block formed by the Haggier 1500 m-high mountains (Fig. 2). These two domains are separated by a NE-SW transfer fault zone dipping toward the northwest. The hanging wall of the transfer zone corresponds to the tilted blocks bounded by $\mathrm{N} 110^{\circ} \mathrm{E}$ normal faults and possess a Quaternary relief lower than the footwall which is the main basement outcrop of the Island (Fig. 2).

Three main basement outcrops can be observed in the island (Fig. 2), which correspond to three basement highs located at the head of tilted blocks. The Qalansya and the Sherubrub areas are located in the western part of the island and both represent respectively $c a .65 \mathrm{~km}^{2}$ and $50 \mathrm{~km}^{2}$. The most voluminous basement outcrop, the Mont-Haggier basement high representing ca. $580 \mathrm{~km}^{2}$ is located at the eastern part of the island. The Neoproterozoic basement of Socotra displays a great variety of metamorphic, plutonic and volcanic rocks previously studied by Beydoun and Bichan (1970). They have evidenced that the oldest part of this basement is made of amphibolite facies meta-sediments and meta-igneous rocks which have been intruded by synkinematic granites and late-kinematic gabbros. Post-kinematic igneous activity gave rise to a sequence of volcanic rocks, hornblende/biotite and peralkaline granites, gabbros and minor intrusions, which make up the bulk of the Haggier mountains. At the footwall of the major tranfer fault of Socotra, Beydoun and Bichan (1970) have evidenced an association of bedded mudstones, sandstone and tuffs belonging to the Hadibo series. Beydoun and Bichan (1970) proposed that: (i) metamorphic events and synkinematic plutonic rocks are Precambrian in age, (ii) the Hadibo series is late pre-Cambrian, and (iii) the peralkaline granites are Early Paleozoic.

The reconstruction of the Gulf of Aden shows that the Socotra Island has occupied, prior to the Oligo-Miocene rifting, a position close to the Precambrian Mirbat and Al Halaaniyat Islands outcrops in Oman (Figs. 1b, e.g. d'Acremont et al., 2006; Leroy et al., 2010a). Gass et al. (1990), based on few geochemical and $\mathrm{Rb} / \mathrm{Sr}$ whole-rock ages ranging from $850 \pm 27 \mathrm{Ma}$ to $706 \pm 40 \mathrm{Ma}$, proposed that Precambrian rocks of Oman lie within the Pan-African domain s.l. and are not part of an older basement such as that identified in eastern Saudi Arabia (Afif and Al-Mahfid Terranes, Fig. 2b). Mercolli et al. (2006) defined four units in the Neoproterozoic basement of Mirbat. The Juffa group corresponds to alternation of paragneisses, amphibolites and few meta-ultramafic lenses. $\mathrm{U}-\mathrm{Pb}$ ages on zircon and $\mathrm{Pb}-\mathrm{Pb}$ ages on garnet clustering around $815 \mathrm{Ma}$ are interpreted as the age of the metamorphism in amphibolite facies (Mercolli et al., 2006). The Sadh Group corresponds to two types of orthogneisses dated by $\mathrm{U}-\mathrm{Pb}$ in situ method on magmatic looking zircons at $816 \pm 12 \mathrm{Ma}$ and $799 \pm 5$ Ma (Mercolli et al., 2006). The Tonalite Group including three kilometre-scale calc- 
138 alkaline plutons was dated by U-Pb in situ method around 780-790 Ma (Mercolli et al., 2006).

139 Finally, the Granite Group comprises: (i) different types of dikes and small bodies of granite 140 dated by step leaching $\mathrm{Pb} / \mathrm{Pb}$ on garnet between 770 and $750 \mathrm{Ma}$, (ii) two small granitic 141 plutons without precise ages, (iii) basaltic to rhyolitic Shaat Dike Swarm without precise age.

142

143

\section{Petrographic and microstructural study of the Socotra basement}

The Neoproterozoic basement of Socotra displays a great variety of metamorphic, plutonic and volcanic rocks. A preliminary map of the various lithological formations was performed by Beydoun et al. (1970). We have completed and modified this map for the three principals inliers of Neoproterozoic rocks by field study and satellite images (Fig. 2 and 3). This section describes the different lithological formations of the Socotra basement.

\section{The metamorphic basement}

The metamorphic basement corresponds to an alterning of quartzites, paragneisses, micaschists, orthogneisses and ortho-amphibolites. Paragneisses and red or white quartzites crop out on large kilometre scale area. Orthogneisses and ortho-amphibolites are observed as metre to hectometre-scale lenses (Fig. 4a) or boudins in paragneisses and quartzites. Finally micaschists are only locally observed.

Micaschists consist of quartz, biotite, muscovite and locally andalusite. Paragneisses display paragenesis of quartz, alkali feldspar, plagioclase, biotite, muscovite, sillimanite and locally relictual andalusite (Fig. 4b). These two-micas micaschists and paragneisses seem to be derived from the same metapelitic protolith affected by different grades of metamorphism. Paragneisses show frequently evidences of partial melting and correspond to metatexites (Fig. 4b), with $30 \%$ max. of leucosomes. In two areas migmatites are strongly evolved and correspond to diatexites (e.g. Menhert, 1968), which contain an important amount of cordierite. Orthogneisses are composed mainly by porphyric alkali feldspar, quartz and biotite (= augengneisses). Amphibolites correspond to former sills of mafic rocks (Fig. 4a), probably gabbros as shown by observations of relictual orthopyroxene and plagioclase laths (Fig. 4c), affected by a HT-LP metamorphism with neo-formation in the amphibolite-facies of $\mathrm{Hb}+\mathrm{Ep}+\mathrm{Ab}$ and coeval deformation. 
Rocks of the metamorphic basement show a well-defined foliation associated to multiscale folding. Foliations and contact between the different metamorphic formations are generally steeply dipping and oriented on average at $c a$. N80 E. Syn-kinematic neo-formed sillimanite which replaces andalousite observed as relic in paragneisses (Fig. 4b), and spectacular anatexis phenomena with leucocratic/melanocratic banding paralell to the foliation show that an important HT-LP metamorphism under amphibolite facies conditions affected the oldest rocks of Socotra during the main deformation event.

\section{The volcanic series}

To the south of the Mont-Haggier area the metamorphic unit is overlain by an association of pyroclastic and effusive rocks belonging to the Southern Haggier volcanic series. Contact between these two units is subhorizontal and devoid of evidence of deformation. The effusive rocks correspond to an alterning of rhyolitic, andesitic, dacitic and basaltic lavas. Pyroclastic rocks, together with thin lava flows, are mainly located to the west of the volcanic formation (Beydoun and Bichan, 1970) and show an alternation of breccias (Fig. 4d), agglomerates, and tuffs (Fig. 4e). Although volcanic rocks are devoid of evidence of deformation and of large metamorphism overprint, we observed locally at the base of the volcanic complex some evidences of HT metamorphic overprint marked by replacement in basaltic lava of pyroxene minerals by hornblende.

At the footwall of the transfer fault, close to Hadibo, we have observed very peculiar yellowish basalt (sample SP15A, localization in figure 2) with a doleritic texture. This basalt (Fig. 4f) is intruded by the Haggier pink granite (see below). Relationships between this basalt and the Southern-Haggier volcanic series are difficult to determine. we observed on a hundred metres long banks along the road, several sheets of more or less differentiated plutonic rocks on a short distance (Fig. 5A). Petrographically fine-grained

The mafic to intermediate plutonic sheets

To this group belong several hectometre to metre thick sheets of tonalites, granodiorites and diorites that have intruded the metamorphic basement in Qalansya, Haggier and Sherubrub areas, and that were successively deformed under amphibolite facies conditions.

We studied in detail this group in the western part of the Qalansya basement high, where tonalites and medium to coarse-grained granodiorites are composed of 30 to $40 \%$ of plagioclase, 30 to $40 \%$ of quartz, 10 to $25 \%$ of alkali felspar and $10 \%$ of mafic minerals 
206 (green hornblende and biotite). We have observed also magnetite, zircon, apatite and sphene.

207 Diorites are fine to medium-grained and composed of 40 to $60 \%$ of plagioclases, 30 to $40 \%$ 208 of green hornblende. We have observed also quartz and accessory minerals corresponding 209 mainly to magnetite, allanite, zircon, apatite and sphene. Locally these rocks are affected by 210 intense metamorphic recrystallization under amphibolite facies conditions as shown by the 211 growth of secondary hornblende, albite and epidote (Figs. 5 B-a and B-b).

212 Emplacement of diorites, tonalites and granodiorites occurred probably by successive 213 pulses as shown by the sharp contacts between the different sheets of these rocks (Fig. 5 B-c 214 and B-d). We observed also sometimes mingling between diorites and granodiorites 215 suggesting that emplacement of successive pulses occurred rapidly (Fig. 5 B-e). These 216 diorites and granitoids display a discrete steeply dipping foliation oriented $\mathrm{N} 80^{\circ} \mathrm{E}$ and a 217 subvertical stretching lineation marked by disposition of neo-formed hornblende grains along 218 their long axis (Fig. 5 B-b and B-f). Dikes of microgranite, aplite and basalt have later 219 intruded the sheets of mafic to intermediate plutonic rocks.

\section{The layered gabbros}

Two km-scale bodies of layered gabbros occur in Socotra. The Haggier layered gabbros intruded the metamorphic basement, covers $c a .40 \mathrm{~km}^{2}$ of low rusty-looking hills to the E-SE of Hadibo. These gabbros are devoid of any solid-state deformation and present a magmatic layering (Fig. 6a) with a rhythmic alternation of pyroxene and plagioclase-rich layers. These layers vary from a few millimetres, where individual bands can be traced over a distance of several metres, to several centimetres in thickness. Petrographically, medium to coarsegrained gabbros show a cumulate texture and consist of 60 to $80 \%$ of zoned labradorite and 40 to $20 \%$ of mafic minerals (Fig. 6b). Mafic minerals consist of clinopyroxene, orthopyroxene and more rarely olivine replaced by hornblende and locally by chlorite and tremolite-actinolite that attests that a middle grade metamorphic event, followed by a lowgrade event, have affected these gabbros. Accessory minerals correspond mainly to magnetite.

The Sherubrub gabbros cover a surface of $c a .6 \mathrm{~km}^{2}$ in the western part of the area and show the same petrographic characteristics as the Haggier layered gabbros. These gabbros are locally associated with intermediate rocks as tonalites and granodiorites and present magmatic layering (Fig. 6c and d). 
Two kilometre-scale bodies of granitic rocks crop out in Socotra: the Sherubrub pluton and the Mont-Haggier pluton.

The Sherubrub pluton and its satellites cover half the Sherubrub area on $c a .25 \mathrm{~km}^{2}$. It is made up mainly of pink medium-grained hypersolvus granite which contains $40 \%$ of quartz, $30 \%$ of microcline, $20 \%$ of perthitic orthoclase, biotite and green hornblende (Fig. 7a and b). Accessory minerals correspond mainly to magnetite, zircon, apatite and euhedral sphene. Myrmekite is generally abundant at the contact between plagioclase and K-feldspar. Many metre to hectometre-scale enclaves and raft of country rocks have been observed in this granite (Fig. 7c). We also found in the Sherubrub pluton some bodies of grey and mediumgrained granite (Fig. 3). The pluton is associated in its periphery with a spectacular swarm of pegmatites which are intrusive in paragneisses and gabbros (Fig. 7d). The Sherubrub pluton shows sharp and subvertical contacts with it country rocks. Microstructural study indicates that the Sherubrub granites present a progressive evolution from the core of the pluton where sub-solidus deformation occurred (Fig. 7a) to the contact where high-temperature solid state deformation occurred (protomylonites) and where we have measured sub-vertical E-W foliation planes (Fig. 7b)

The Mont-Haggier pluton consists of two major facies covering ca. $250 \mathrm{~km}^{2}$. The Northern-Haggier biotite granite covers $c a .60 \mathrm{~km}^{2}$ around Hadibo. It corresponds to a light grey and medium-grained granite which contains $40 \%$ of quartz, 20 to $30 \%$ of zoned plagioclase, 20 to $30 \%$ of myrmekitic alkali felspar and $10 \%$ of biotite and green hornblende (Fig. 7e). Accessory minerals correspond to apatite, zircon, magnetite and other opaque minerals. Granite is associated with many mafic enclaves. Locally granites are more leucocratic and present rare muscovite. Microstructural study indicate that the NorthernHaggier biotite granite has suffered a very weak solid-state deformation marked by internal deformation and reorientation of quartz grains (Fig. 7e). The Haggier pink granite covers $c a$. $200 \mathrm{~km}^{2}$ in the centre of the Haggier basement high and can be studied on a natural vertical cross-section of 1,500 metres. This granite is pinkish to reddish (Fig. $7 \mathrm{f}$ and $8 \mathrm{a}$ ), and generally coarse-grained. Quartz $(\sim 30 \%)$ and perthitic alkali feldspar $(\sim 60 \%)$ with subordinate albite grains are the main components. We observed also rare arfvedsonite (Fig. 8b), zircon, monazite and magnetite. The Haggier pink granite is generally devoid of internal deformation, even though few thin-sections display quartz grains deformed under high-temperature 
conditions (chessboard texture, Fig. 8c). The eastern contact of the Haggier pink granite with the layered gabbros, which correspond to the bottom of the pluton, is diffuse, characterized by spectacular magmatic "breccias" (Fig. 8a), and dip moderately at map scale. Magmatic "breccias" are characterized by stronly angular and numerous enclaves of gabbro in granites showing that the gabbros were crystallized at the time of granite intrusion. The southern and western limits of the pluton show sharps and subvertical contacts with the Southern Haggier volcanic series that may be followed for several kilometres. Study of the various contacts suggest that the pluton were developped mainly in the Southern Haggier volcanic series at the top of the Haggier layered gabbros. Finally, we observed from top to bottom of the batholith, an evolution of the texture of the granites, coarse-grained in the major part of the outcrop, and fine-grained in the western part of the Mont-Haggier area close to the contact with the Cenozoic and Mezosoic series.

\section{The Haggier dike swarm}

A spectacular amount of dikes has been observed in the Mont-Haggier area. We have not performed an exhaustive mapping of these dikes. Only the largest ones have been represented on the petrographic map (Fig. 2). We distinguish three generations: (i) dikes of microgranites, (ii) basaltic and andesitic dikes, (iii) dacitic and rhyolitic dikes.

Dikes of pink to red and fine grained granite are clearly associated with the pink Haggier granite intrusion and are ubiquous to the west and to the north of this intrusion. Metre to hectometre-scale microgranitic dikes present a microgranular porphyric texture with the same mineral association as the Haggier pink granite. While measurements of dikes of pinkish microgranites show some disparities (Fig. 9a), a major family can be easily identified, oriented on average around $\mathrm{N} 33^{\circ} \mathrm{E}$ and subvertical.

Numerous volcanic dikes are intrusive in all the formations of the Mont-Haggier area. The pink Haggier granite is devoid of mafic dikes and is only cut by numerous rhyolitic dikes. Mafic dikes are homogeneously oriented (mean at N59 ${ }^{\circ}$, Fig. 9b) and correspond dominantly to basaltic dikes, rich in green hornblende and plagioclase, with a doleritic texture (Fig. 8d and e). Rhyolitic dikes (Fig. 8f) are homogeneously oriented (mean at N41 ${ }^{\circ}$ E, Fig. 9c) and display a microlithic-porphyric texture with orthoclase megacrysts. 
Several mafic and felsic rocks from Mont-Haggier, Sherubrub and Qalansya basement were sampled for whole-rock analysis (Table 1). Mafic rocks were picked up at Mont Haggier and Qalansya areas whereas analysed felsic rocks were selected from Mont Haggier and Sherubrub samples.

Mafic rocks

313

According to geochemical data, mafic rocks from Socotra Island suffered different degrees of alteration. The Haggier layered gabbros are the least altered rocks with Loss on Ignition (LOI) below 1.6 wt.\%. Most Basaltic dikes belonging to the Haggier dike swarm (SP10 and SP18), basaltic lava (S20) and tuff (SP16B) from the Southern Haggier volcanic series are significantly altered with LOI up to 3.8 wt.\% (Table 1). Diorites (CS14A and CS18A) from the mafic to intermediate plutonic sheets of Qalansya are almost fresh rocks (LOI $=2.01$ wt.\% and 0.98 wt.\%). The yellowish basalt croping out in the Northern part of the Mont-Haggier area is highly altered (SP15A: LOI = 5.99 wt.\%).

Major elements composition of volcanic and subvolcanic rocks from Mont-Haggier are in good agreement with those of basalts, basaltic andesites and andesites (Table 1), even though $\mathrm{MgO}$ and $\mathrm{CaO}$ concentrations are significantly low most likely due to strong differentiation process. According to the $\mathrm{SiO}_{2}$ vs $\mathrm{K}_{2} \mathrm{O}$ diagram (Fig. 10), three volcanic and subvolcanic rocks (SP10, SP16bB and SP18A) are calc-alkaline in composition whereas the yellowish basalt SP15A belong to the high-K calc-alkaline to shoshonitic field. However, due to high LOI values, such discrimination should be used with caution. For example, sample S20 falls in the arc tholeiites series field most likely due to Large-Ion Lithophile Element (LILE) leaching during alteration process. Diorites of Qalantsya are calc-alkaline (CS18A) or high-K calc-alkaline (CS14A) in composition. Mafic to intermediate rocks from MontHaggier show a wide range of $\mathrm{Al}_{2} \mathrm{O}_{3}$ (13.52-26.32 wt.\%), $\mathrm{Fe}_{2} \mathrm{O}_{3}$ (2.71-13.99 wt.\%), $\mathrm{CaO}$ (5.20-14.78 wt.\%), $\mathrm{MgO}$ (2.43-7.55 wt.\%), $\mathrm{TiO}_{2}$ (0.18-2.56 wt.\%) and $\mathrm{Mg \#} \mathrm{(17-56)} \mathrm{reflecting}$ difference between gabbro cumulates and non-cumulative rocks. Mafic to intermediate rocks from Qalansya display almost homogeneous geochemical composition except for $\mathrm{SiO}_{2}(49.38$ vs. 54.55 wt.\%) and $\mathrm{Fe}_{2} \mathrm{O}_{3}$ (8.48 vs. 11.15 wt.\%). According to trace elements data, two different signatures can be distinguished from non-cumulative rocks (Fig. 11a and Fig. 11c; Table 1). The first signature recorded in the basalt SP15A and in the diorites of Qalansya, is 
characterized by low $\mathrm{Nb}$ and $\mathrm{Ta}$ negative anomalies $\left(\mathrm{La}_{\mathrm{N}} / \mathrm{Nb}_{\mathrm{N}}=3-4\right)$ indicative of suprasubduction setting and by low LILE and LREE enrichment (e.g. $\mathrm{Ce} / \mathrm{Yb}<15)$ underlined by a relatively flat multi-element patterns in Figure 9a. The second signature, which is recorded in the volcanic and subvolcanic rocks of Mont-Haggier area shows a large negative $\mathrm{Nb}$ and Ta anomaly $\left(\mathrm{La}_{\mathrm{N}} / \mathrm{Nb}_{\mathrm{N}}>7\right)$ and shows significant enrichment in LILE and LREE (e.g. $\mathrm{Ce} / \mathrm{Yb}>>15$ ) characteristic of volcanic arc basalts. In Figure 11d, the first group belongs to the arc calc-alkaline basalts field and the second group plots in the transitional arc basalts field and is close to arc tholeiite basalts (i.e. immature arc basalt) and back-arc basalt field. Gabbro cumulates (Fig. 11a and Fig. 11b) are geochemically related to the second group as underlined by chondrite-normalized rare earth elements diagram (Fig. 11b) which emphasizes an evolution by fractional crystallization process. As a consequence, major and trace elements composition of mafic to intermediate rocks highlights existence of two distinct geochemical compositions in Socotra basement (Figure 11a, 11c and 11d; Table 1): (i) a signature diagnostic of a depleted-arc or back-arc basin setting, and (ii) a signature characteristic of enriched-arc setting.

\section{Felsic rocks}

Felsic rocks from the Haggier dike swarm, and the Haggier and Sherubrub plutons display a moderate range of chemical composition (Table 1) with high $\mathrm{SiO}_{2}$ content (71.6778.50 wt.\%), low to moderate contents of $\mathrm{Al}_{2} \mathrm{O}_{3}$ (11.22-14.34 wt.\%) and $\mathrm{Fe}_{2} \mathrm{O}_{3}(0.91-3.47$ wt.\%), low levels of $\mathrm{MgO}$ and $\mathrm{TiO}_{2}(<0.53$ wt.\% and $<0.37$ wt.\% respectively), and moderate to high alkalies concentrations $\left(\mathrm{Na}_{2} \mathrm{O}: 2.95-5.33\right.$ wt.\%; $\mathrm{K}_{2} \mathrm{O}: 3.02-5.81$ wt.\%). In Figure $12 \mathrm{a}$, felsic rocks are distributed between peraluminous, metaluminous and peralkaline fields although most analyses are characterized by a metaluminous composition. Trace elements data underlines wide variations in MREE, HREE, Zr and Hf, whereas LILE (except $\mathrm{Ba}$ ) and LREE composition exhibit a relative narrow range of composition (Fig. 12b) resulting in relatively low LREE/HREE ratios (e.g. $\mathrm{La}_{\mathrm{N}} / \mathrm{Yb}_{\mathrm{N}}<6.7$ ). $\mathrm{Nb}$ and Ta may be highly variable but always display negative anomalies on silicate Earth-normalized multi-elements diagram (Fig. 12b). Based on the plot of $10000^{*} \mathrm{Ga} / \mathrm{Al}$ vs. $\mathrm{Zr}+\mathrm{Nb}+\mathrm{Y}+\mathrm{Ce}$, felsic rocks from both Mont Haggier and Sherubrub areas fall in the field of A-type granite except for two samples which belong to the field of I-M-S-type granites (Fig. 12c). However, in similar plots (i.e $10000 * \mathrm{Ga} / \mathrm{Al}$ vs. $\mathrm{Nb} ; 10000 * \mathrm{Ga} / \mathrm{Al}$ vs. $\mathrm{Y} ; 10000 * \mathrm{Ga} / \mathrm{Al}$ vs. Ce; not shown) analyses show a complex and transitional signature as they fall between fractionated I-type granite and 
A-type granite fields. On a discrimination diagram (Fig. 12d), felsic rocks plot both within the volcanic arc/syn-collision and oceanic ridge granites fields, except for one sample located in the within plate granite field. Thus, geochemistry of felsic rocks from Socotra is not entirely consistent with anorogenic (ORG and WPG) and orogenic (VAG) signature and their emplacement in Cryogenian in a back-arc setting cannot be ruled out.

\section{U/Pb data}

Three samples were collected for zircon U-Pb dating. HAEU-1 and HAEU-2 (localization in fig.2) were collected in the Mont-Haggier area. HAEU-1 is representative of the Haggier pink granite. HAEU-2 corresponds to an enclave of gabbro in the Haggier pink granite, showing the same petrographic characteristics of the Haggier layered gabbros. Other sample (SHEU-1, localization in fig.3) collected in the Sherubrub basement high, is representative of the pinkish granite of the Sherubrub pluton.

Zircon grains from each sample were selected by hand-picking from 50-300 $\mu \mathrm{m}$ fractions and mounted in epoxy resin together with fragments of the 91,500 standard zircon, dated at 1062.4 \pm 0.4 Ma [Ontario, Canada; Wiedenbeck et al., 1995]. Mounts were then polished and gold coated. U-Pb isotopic compositions were determined in situ using the CRPG-CNRS Cameca IMS-1270 ion microprobe (Nancy, France). Further information on instrumental conditions and data reduction procedures is given in Deloule et al. (2002). Concordia diagrams and discordia lines were constructed using the Isoplot program (Ludwig, 2003). In the forthcoming paragraphs, we use ${ }^{206} \mathrm{~Pb} /{ }^{238} \mathrm{U}$ ages for concordant data, rather than ${ }^{207} \mathrm{~Pb} /{ }^{235} \mathrm{U}$ ages, which are more sensitive to common lead contribution (the ${ }^{207} \mathrm{~Pb}$ ion signal is about ten times lower than the ${ }^{206} \mathrm{~Pb}$ ion signal). Discordant data were used on the concordia diagrams to calculate possible discordia lines.

Eleven anhedral to squat zircon grains were analysed for sample HAEU-1 and for each crystal core and rim were analysed (Table 2). Analyses show very small common lead contribution but significant $\mathrm{Pb}$ losses. One zircon grain provides a concordant ${ }^{206} \mathrm{~Pb} /{ }^{238} \mathrm{U}$ age at $858 \pm 11 \mathrm{Ma}$ and is interpreted as an inherited core. The remaining ten analyses are subconcordant or discordant. Regression curve calculated from these zircon grains gives a discordia line (Fig. 13a) with an upper intercept at $816 \pm 12 \mathrm{Ma}(\mathrm{MSWD}=0.49)$.

Eleven zircon grains were analysed for sample HAEU-2 and for each crystal core and rim were analysed (Table 2). Based on morphology, two types of zircons can be identified: (i) 
euhedral and acicular crystals and (ii) anhedral to subhedral and squat crystals. Data show very small amount of common lead $(\mathrm{Pbc}<1 \%)$ but some exhibit slight $\mathrm{Pb}$ or $\mathrm{U}$ losses. One zircon grain gives concordant ${ }^{206} \mathrm{~Pb} /{ }^{238} \mathrm{U}$ age at $856 \pm 12 \mathrm{Ma}$ and most likely corresponds to an inherited core. Seven of the remaining eleven analyses are scattered along discordia line (Fig. 13b) defining an upper intercept at $825 \pm 18 \mathrm{Ma}(\mathrm{MSWD}=0.49)$. Mean ${ }^{206} \mathrm{~Pb} /{ }^{238} \mathrm{U}$ age of $821 \pm 16 \mathrm{Ma}(\mathrm{MSWD}=0.53)$ was calculated from four subconcordant analyses. Since gabbro enclaves are intruded by some granitic veins, we assume the presence of two population of zircon: (i) one associated with the gabbro enclaves and (ii) and the other crystallized from the granitic intrusions and veins. However, taking into account the low zirconium concentrations of gabbros and the very low abundance of zircon observed in thin sections, we assume that most zircon crystals separated from HAEU-2 belong to granitic intrusions and veins. Even if some zircon grains from gabbros enclaves have been analysed, homogenous distribution of data observed in Fig.13b indicates a relative contemporaneity (within $206 \mathrm{~Pb} / 238 \mathrm{U}$ age errors) of mafic and felsic magmatism. Whatever, calculated $\mathrm{U}-\mathrm{Pb}$ age is identical within errors to age obtained for the sample HAEU-1 and is interpreted as the age of emplacement of the Haggier pink granite.

In the Sherubrub granite (sample SHEU-1), zircon grains are euhedral, prismatic and acicular. One zircon analysis displays slight loss of uranium linked to a reopening of the U-Pb system. The remaining seven analyses are subconcordant to discordant. Regression of these zircon analyses provides a discordia line (Fig. 13c) with an upper intercepts at $812 \pm 27 \mathrm{Ma}$ $(\mathrm{MSWD}=1.8)$. This age is in good accordance with ages acquired from the only concordant analysis on a Tera-Wasserburg diagram (not shown) i.e. $809 \pm 13 \mathrm{Ma}\left({ }^{206} \mathrm{~Pb} /{ }^{238} \mathrm{U}\right.$ age) and $815 \pm 11 \mathrm{Ma}\left({ }^{207} \mathrm{~Pb} /{ }^{235} \mathrm{U}\right.$ age $)$.

\section{Discussion}

The oldest rocks of Socotra correspond mainly to an association of paragneisses and quartzites forming the metamorphic basement. Protolith of these rocks probably correspond to an alternation of metapelite, sandstone and argillaceous sandstone which could correspond to delta or continental shelf deposits. These rocks were metamorphosed and deformed under 
and granites which now form interfoliated lenses or boudins of ortho-amphibolites and orthogneisses. These metamorphic rocks show many lithological similarities with the Juffa group in Oman (Mercolli et al., 2006) which corresponds to an alternation of paragneisses, micaschists and ortho-amphibolites, and the Banded Gneiss Complex which corresponds to an association of augengneisses and biotite-hornblende gneisses. Steep foliation planes and contacts between the various units of the metamorphic basement of Socotra suggest that metamorphism and deformation occurred in a compressive or in a transpressive regime. Our $\mathrm{U}-\mathrm{Pb}$ data in granites show scarcity of inherited cores represented by two zircons with $\mathrm{U}-\mathrm{Pb}$ ages at ca. $860 \mathrm{Ma}$. These measurements suggest that the orthogneisses, migmatites and orthoamphibolites of Socotra are younger than 860 Ma. This is consistent with both datation of emplacement of the protolith of the orthogneisses of the Banded Gneiss Complex and datation of the metamorphic event in the Juffa Group and the Banded Gneiss Complex around $815 \mathrm{Ma}$ obtained by Mercolli et al. (2006). However we have no elements to precise the age of the protoliths of the paragneisses and quartzites that could be of Mesoproterozoic age as the Juffa Group in Mirbat (Mercolli et al., 2006).

\section{Mafic intrusions on the Cryogenian active margin of Socotra}

Metamorphic rocks of the Socotra basement have been intruded by voluminous mafic and felsic magmatic bodies. Field relationships show that felsic intrusions occur generally later than the mafic to intermediate one. Mafic to intermediate bodies of Socotra show some evidences of metamorphic overprint in amphibolite facies conditions. However these rocks have not suffered the strong solid-state deformation recorded by the metamorphic basement and are devoid of evidence of partial melting. Emplacement of mafic to intermediate intrusions is thus late-kinematic and post-date metamorphic peak. The mafic to intermediate plutonic sheets have been affected by an incipient solid-state deformation and show discrete steeply dipping foliation planes parallel to those of the metamorphic basement. These sheets correspond probably to the first mafic intrusions.

Mafic rocks were characterized by two distinct signatures. A signature diagnostic of a depleted-arc or back arc basin $\left(\mathrm{Ce} / \mathrm{Yb}>15 ; \mathrm{La}_{\mathrm{N}} / \mathrm{Nb}_{\mathrm{N}}>7\right)$ is recorded in the mafic rocks belonging to the Mont-Haggier area as the Haggier layered gabbros, the basaltic lavas of the Southern Haggier volcanic series and the mafic dikes of the Haggier dike swarm. The Haggier mafic system allows thus the observation of a well-preserved upper part of a juvenile arc or a back-arc basin (Fig. 14), with a magmatic chamber characterized by crystallization of 
cumulates, volcanic effusions in surface and formation of a dike swarm which allowed the magmas to be transfered from the magmatic chamber to the surface. The second signature of mafic to intermediate rocks is characteristic of enriched-arc setting $(\mathrm{Ce} / \mathrm{Yb}>15 ; \mathrm{La} / \mathrm{Nb}>$ 6.5) and is evidenced in the yellowish basalt SP15A and in the diorites of the mafic to intermediate plutonic sheets of Qalansya. The low contents of HREE compared to the orthers REE of the sample SP15A (e.g. La/Yb $>80$ ) could indicate the presence of garnet in the source of this basalt and thus a genesis at high depth.

Geochemical compositions of the mafic rocks of Socotra indicate clearly a suprasubduction context during the middle Neoproterozoic times (Cryogenian). The first mafic rocks were emplaced in a context of an enriched-arc setting forming probably in an Andean-type arc. By contrast the last emplaced mafic rocks of Socotra are characteristic of a depleted-arc context which could correspond to the formation of either (i) an intra-oceanic island-arc, (ii) or an island-arc above a thinned continental crust, or (iii) a back-arc basin. By considering that the basement of Socotra is affected by an important HT-LP metamorphism prior and coevally with the formation of the depleted-arc, we suggest that emplacement of mafic rocks presenting a depleted-arc signature occurred during the opening of a back-arc basin. This hypothesis provides also an explanation to understanding the contrasted structural features between the gabbros cumulates characterized by moderately dipping magmatic layering that can be formed during local extensional regime, and steeply dipping calc-alkaline sheets that probably intruded the metamorphic basement during compressive regime. Homogeneous orientation of basaltic dikes around $\mathrm{N} 60^{\circ} \mathrm{E}$ indicates that the back-arc basin (or juvenile arc) of Socotra is probably aligned along the same direction during Cryogenian times (Fig. 14).

The sheets of mafic to intermediate rocks of Socotra correspond probably to an equivalent of the Mahall Complex of Mirbat (Mercolli et al., 2006), which intruded the Juffa group around $800 \mathrm{Ma}$ and and corresponds to original dioritic and tonalitic plutons that have been deformed and recrystallised under amphibolite facies conditions. The juvenile arc system of Socotra including cumulates, basaltic dikes and tholeitic lavas could correspond to an equivalent of the Tonalite Group in Mirbat which have been dated between 790 and 780 Ma and have never suffered solid-state deformation (Mercolli et al., 2006). The Tonalite Group comprises two small bodies of hornblende bearing layered olivine gabbroic intrusions which are petrographically similar to the Haggier layered gabbro body, and two kilometrescale tonalite to granodiorite layered plutons, the Hadbin and Fusht Complex. Al-Kathiri (1998) suggested that the layered gabbros of Mirbat represent the parental magmas from 
which the dioritic-tonalitic rocks of the Fusht and Hadbin complex evolved by hornblende dominated fractionation. Although in Mirbat volcanic rocks that could correspond to the Southern Haggier volcanic Series were never found, volcanic clasts are very abundant in the sediments of the Ediacaran clastic Mirbat formation (Mercolli et al., 2006). This suggest that the volcanic series representing the upper crustal level during Cryogenian times were largely eroded during Ediacaran in the Mirbat basement as in the western part of the Socotra Island.

The Cryogenian High-K calc-alkaline intrusions of Socotra

The Sherubrub pluton intrusive in the Sherubrub gabbro and in the metamorphic basement shows systematic vertical and sharp contacts with it country rocks. While emplacement of this pluton is clearly post-metamorphic peak, strong high to middle temperature deformation at the contact with it country-rocks associated with a sub-vertical solid-state foliation suggests a syn-collisional emplacement in compressive regime. The Haggier pink granite was clearly intrusive at the top of the Haggier layered gabbros (Fig. 14) when these gabbros were crystallized as shown by the presence of magmatic breccia. These granites have suffered a very weak deformation and emplaced at the top of the upper crustal domain as shown by their textural evolution from the top to the base of the pluton. Finally the Northern Haggier biotite granite crops out in a low-relief zone and we were not able to study relationship between this granite and its country-rocks. This granite is intruded by some basaltic dikes (Fig. 14) presenting the same geochemical affinity of the Haggier layered gabbros. We can thus suggest that emplacement of the Northern Haggier biotite granite is coeval with the final stage of emplacement of mafic rocks. Whereas $\mathrm{U}-\mathrm{Pb}$ datation on the Haggier pink granite and the Sherubrub granites present important uncertainties, ages are very close and suggest in accordance with geochemical data that felsic plutons of Socotra were emplaced during the same magmatic activity which occurred between 840 and 780 Ma. Granites and felsic dikes present geochemical characteristics which underline their transitional character although with a certain affinity with A-type granites. Also the geochemical diagrams do not associate them with a distinct geodynamic setting, however field relationships suggest that their emplacement occurred by the end of the Cryogenian active margin formation. Orientations of microgranitic and rhyolitic dikes associated with the Haggier pink granite are very close to the orientation of the basaltic dikes, and are thus consistent with this hypothesis (Fig. 14). Moreover structural data in the Sherubrub pluton suggest that their emplacement occured during compressive regime. In this way, emplacement 
of these granites could correspond to the final stage of the orogenic system evolution during the closure of a back-arc system in an Andean type margin.

The Mirbat block presents a later calc-alkaline acidic magmatism event characterized by some hectometric-scale bodies of granite and by the developement of a pegmatitic dike swarm (Mercolli et al., 2006). Mirbat is thus less or not affected by the voluminous highpotassic acidic magmatic event that we have observed in Socotra. Subsequently to these Cryogenian events, the various units of Mirbat recorded fast exhumation (Mercolli et al., 2006). The mirbat basement rocks are overlain by clastic sediments of the Mirbat formation which is probably Ediacaran in age (Mercolli et al., 2006). The Hadibo series (Beydoun and Bichan, 1970) are composed mainly by sandstones. These clastic series are restricted to the footwall of the main transfer fault of Socotra (Fig. 2) and overlain the Cryogenian basement. These series recorded probably as the Mirbat formation, Ediacaran denudation of the Cryogenian basement of Oman.

The Socotra and Mirbat basements in the case of the East-African-Antartic-Orogen

Our study of the Neoproterozoic Socotra basement underlines formation of a juvenile arc system and/or back-arc basin with some evidences of evolution from an Andean-type arc. Formation of this system is late compared to a stage of HT-LP metamorphism that was recorded in the older metasedimentary rocks of Socotra. Although we have insufficient geochronological data to constrain the ages of the earliest events recorded in the Socotra basement, we can claim on the basis of our data on Socotra and by analogy with the Mirbat block in Oman: (i) that the basement of Socotra is affected by a high temperature metamorphic stage whose minimum age is $815 \mathrm{Ma}$; (ii) that the metamorphic basement is first intruded by mafic to intermediate rocks related to an Andean type arc and secondly by mafic rocks related to a juvenile arc/or back-arc basin; and (iii) that the arc system is intruded by large acidic plutons with a transitional affinity, these plutons being characterized by a minimum age at $780 \mathrm{Ma}$.

The comparison of these characteristics with those of the various domains of the EAAO provides more information. Between 700 and $600 \mathrm{Ma}$, the ANS suffered a low to medium grade metamorphism linked to terrane accretion. This metamorphic stage is younger than the juvenile arc formation which occurred mainly between 800 and $700 \mathrm{Ma}$ (e.g. Nehlig et al., 2002; Johnson and Woldehaimot, 2003). The Mozambic belt in the central and southern part of the EAAO is characterized by coeval deformation and high-temperature metamorphism, 
marked by formation of granulites, between ca. 600 and $540 \mathrm{Ma}$ (Jacobs and Thomas, 2004). The terranes of the continental Yemen show the transition between the ANS and the highgrade rocks of the EAAO. The Al-Mafid and Abas gneiss terranes (Fig. 1b) recorded a major ca. 760 Ma metamorphism and deformational event linked to terranes accretion and marked by $\mathrm{Pb}$ loss in zircons in Archean gneisses and by zircon crystallization ages of granitic gneisses (Whitehouse et al., 1998). Moreover ${ }^{40} \mathrm{Ar} /{ }^{39} \mathrm{Ar}$ ages obtained from intrusive rocks at the boundary between Al-Mafhid and Abas gneiss terranes provide a lower limit of $615 \mathrm{Ma}$ upon terrane assembly (Whitehouse et al., 1998). The basements of Socotra and Mirbat present a high-grade metamorphic stage earliest than that recorded in the pan-african EAAO. The magmatic rocks of the ANS present generally a typical volcanic-arc signature while the magmatism of Socotra shows a complex evolution in a short time span with very peculiar geochemical signatures, that suggest an evolution from an Andean-type arc to a juvenile arc/back-arc basin with later emplacement of large high-potassic plutons. Finally, structural studies indicate that the major foliation planes are homogeneously oriented between $\mathrm{N} 70^{\circ} \mathrm{E}$ and $\mathrm{N} 80^{\circ} \mathrm{E}$ in Socotra and Mirbat (Mercolli et al., 2006), whereas the main directions underlined in the ANS are NS to NW-SE (Johnson and Woldehaimot, 2003, references therein).

These comparisons suggest that the basement of Mirbat and Socotra were formed in a different geodynamic setting from those of the ANS and the high-grade Mozambic belt of the EAAO. Though there is a lack of paleomagnetic data to have a detailled paleogeographic reconstruction of this period, we consider following Li et al. (2008) that the microcontinental blocks of Afif-Abbas and Al-Mahfid were placed between India and Sahara in Cryogenian times. Many evidences highlight that a Cryogenian active Andean-type margin was developed on the western part of the Greater India block ( $\mathrm{Li}$ et al., 2008). This active margin has been identified by using integrated geochronological, geochemical and paleomagnetic analysis in Seychelles Islands (Torsvik et al., 2001a; Tücker et al., 2001; Ashwal et al., 2002), in northwestern India with the Malani Igneous Suite (Torsvik et al., 2001b) and in northeastern Madagascar (Tucker et al., 1999a and b). In the Seychelles Islands this active margin is marked by emplacement of two groups of granites dated around $750 \mathrm{Ma}$ : the Mahé group which corresponds to greyish granites and the Praslin group which corresponds to redish to pinkish granites (Ashwal et al., 2002). These two granites present many petrographic and geochemical similarities with both the greyish and pinkish granites of Socotra, which indicates that the Neoproterozoic rocks of Socotra could also form on the Cryogenian 
610 Andean-type margin of the Indian block. This hypothesis would need additional structural, 611 isotopic and more geochronological data to be tested.

612

613

614

615

616

617

618

619

620

621

622

623

624

625

626

627

628

629

630

631

632

633

634

635

636

637

638

639

\section{8} 640 related rocks from the Seychelles: the case for an Andean-type arc origin. J. Petrol. 43: $641 \quad 45-83$.

\section{Conclusion}

The basement of the Socotra Island presents an early high-temperature metamorphism event associated with a strong deformation and then a voluminous mafic and felsic emplacement event. U-Pb data indicate that these successive events occurred during a relative short time span, between 860 and $780 \mathrm{Ma}$ at maximum. Mafic magmatism shows the evolution from an Andean type arc to a juvenile arc/or back-arc basin. Felsic magmatism is characterized by emplacement of voluminous highly potassic calc-alkaline granites forming large plutons and which occurred probably at the final stage of arc history. These granites are not anorogenic as it has been previously published by analogy to the peralkaline granites of the ANS which were emplaced at ca. $600 \mathrm{Ma}$.

These features cannot be easily reconciled with those of the Arabian-Nubian Shield to the west of Socotra and with the Mozambique Belt to the south. We propose that the Socotra basement was developed on an active margin located near the Indian block in Cryogenian times.

\section{Acknowledgements}

We thank Ph. Olivier and L. Siebenaller for constructive discussions.

We also thank P. Barbey and I. Mercolli for their valuable remarks which helped us to improve a first version of this article.

\section{Bibliography}

39 Ashwal LD, Demaiffe D, Torsvik TH (2002) Petrogenesis of Neoproterozoic granitoids and 
Avigad D, Gvirtzman Z (2009) Late Neoproterozoic rise and fall of the northern ArabianNubian shield: The role of lithospheric mantle delamination and subsequent thermal subsidence. Tectonophysics 477: 217-228.

Bingen B, Jacobs J, Viola G, Henderson IHC, Skår Ø, Boyd R, Thomas RJ, Solli A, Key RM, Daudi EXF (2009) Geochronology of the Precambrian crust in the Mozambique belt in NE Mozambique, and implications for Gondwana assembly. Precambrian Res. 170: 231255.

Beydoun ZR, Bichan HR (1970). The geology of Socotra Island, Gulf of Aden. Quaterly J. Soc. Lond. 25: 413-446.

Blasband B, Brooijmans B, Dirks P, Vissers W, White S (1997) A Pan-African core complex in the Sinai, Egypt. Geol. Mijnb. 76: 247-266.

Blasband B, White S, Brooijmans B, De Boorder H, Visser W (2000) Late Proterozoic extensional collapse in the Arabian-Nubian Shield. J. Geol. Soc. Lond. 157: 615-628.

Cabanis B, Lecolle M (1989) Le diagramme La/10-Y/15-Nb/8; un outil pour la discrimination des series volcaniques et la mise en evidence des processus de melange et/ou de contamination crustale. CRAS, Paris 309: 2023-2029.

Collins AS, Pisarevsky SA (2005) Amalgamating eastern Gondwana: the evolution of the Circum-Indian Orogens. Earth-Sci. Rev. 71: 229-270.

Collins AS (2006) Madagascar and the amalgamation of Central Madagascar. Gondwana Res. (GR Focus) 9: 3-16.

d'Acremont E, Leroy S, Maia M, Patriat P, Beslier M-O, Bellahsen N, Fournier M, Gente P (2006) Structure and evolution of the eastern Gulf of Aden: insights from magnetic and gravity data (Encens-Sheba/MD117 cruise). Geophys. J. Int. 165: 786-803.

Deloule E, Alexandrov P, Cheilletz A, Laumonier B, Barbey P (2002) In-situ U-Pb zircon ages for early Ordovician magmatism in the eastern Pyrenees, France: the Canigou orthogneisses. Int. J. Earth Sci. 91: 398-405.

Gass G, Ries AC, Shackleton RM, Smewing JD (1990) Tectonics, geochronology and geochemistry of the Precambrian rocks of Oman. In: Robertson AHF, Searle MP, Ries AC (eds.) The Geology and Tectonics of the Oman Region. Spec. Pub. Geol. Soc. Lond. 49: $585-599$. 
Greiling R O, Abdeen MM, Dardir AA, El Akhal H, El Ramly MF, Kmal El Din GM, Osman AF, Rahwan AA, Rice AA, Sadek MF (1994) A structural synthesis of the Proterozoic Arabian-Nubian shield in Egypt. Geologische Rundshau 83: 484-501.

Johnson PR, Woldehaimanot B (2003) Development of the Arabian-Nubian shield: perspectives on accretion and deformation in the northern East African Orogen and the assembly of Gondwana. In: Yoshida M, Windley BF, Dasgupta S (eds) Proterozoic East Gondwana: Supercontinent Assembly and Breakup. Spec. Pub. Geol. Soc. Lond. 206: 289-325.

Jacobs J, Fanning CM, Henjes-Kunst F, Olesch M, Paech HJ (1998) Continuation of the Mozambique Belt into East Antarctica: Grenville-age metamorphism and polyphase PanAfrican high-grade events in central Dronning Maud Land. J. Geol. 106: 385-406.

Jacobs J, Thomas RJ (2004) Himalayan-type indenter-escape tectonics model for the southern part of the late Neoproterozoic-early Paleozoic East African-Antarctic orogen. Geology 32: $721-724$.

Jacobs J, Thomas RJ (2010) Himalayan-type indenter-escape tectonics model for the southern part of the late Neoproterozoic-early Paleozoic East African-Antarctic orogen. Geol. Soc. Am. 32: 721-724.

Kröner A, Willner AP, Hegner E, Jaeckel P, Nemchin A (2001) Single zircon ages, PT evolution and $\mathrm{Nd}$ isotopic systematics of high-grade gneisses in southern Malawi and their bearing on the evolution of the Mozambique belt in southeastern Africa. Precambrian Res. $109,257-291$.

LeBas MJ, LeMaitre RW, Streckeisen A, Zanettin B (1986) A chemical classification of volcanic rocks based on the total alkali silica diagram. J. Pet. 27:745-750.

Leroy S, Gente P, Fournier M, d'Acremont E, Patriat P, Beslier M-O, Bellahsen N, Maia M, Blais A, Perrot J, Al-Kathiri A, Merkouriev S, Fleury JM, Ruellan PY, Lepvrier C, Huchon P (2004) From rifting to spreading in the eastern Gulf of Aden: a geophysical survey of a young oceanic basin from margin to margin. Terra Nova 16: 185-192.

Leroy S, Lucazeau F, d'Acremont E, Watremez L, Autin J, Rouzo S, Bellahsen N, Tiberi C, Ebinger C, Beslier M-O, Perrot J, Razin P, Rolandone F, Sloan H, Stuart G, Al-Lazki A, Al-Toubi K, Bache F, Bonneville A, Goutorbe B, Huchon P, Unternehr P, Khanbari K (2010a) Contrasted styles of rifting in the eastern Gulf of Aden: a combined wide-angle 
MCS and Heat flow survey. Geochemistry, Geophysics, Geosystems 11 (Q07004):1-14. doi:doi:10.1029/2009GC002963.

705

706

707

708

709

710

711

712

713

714

715

716

717

Leroy S, d'Acremont E, Tiberi C, Basuyau C, Autin J, Lucazeau F, Sloan H (2010b) Recent off-axis volcanism in the eastern Gulf of Aden: implications for plume-ridge interaction. Earth Planet Sci. Lett. 293 (1-2):140-153. doi:10.1016/j.epsl.2010.02.036.

Leroy S, Razin P, Autin J, Bache F, d'Acremont E, Watremez L, Robinet J, Baurion C, Denèle Y, Bellahsen N, Lucazeau F, Rolandone F, Rouzo S, Serra Kiel J, Robin C, Guillocheau F, Tiberi C, Basuyau C, Beslier M-O, Ebinger C, Stuart G, Sloan H, Ahmed A, Khanbari K, Al-Ganad I, de Clarens P, Unternehr P, Al-Toubi K, Al-Lazki A (submitted in this volume) Rifting to spreading in the Gulf of Aden.

Li ZX, Powell CM (2001) An outline of the Palaeogeographic evolution of the Australasian region since the beginning of the Neoproterozoic. Earth-Sci. Rev. 53: 237-277.

Li ZX, Bogdanova SV, Collins AS, Davidson A, De Waele B, Ernst RE, Fitzsimons ICW, Fuck RA, Gladkochub DP, Jacobs J, Karlstrom KE, Lu S, Natapov LM, Pease V, Pisarevsky SA, Thrane K, Vernikovsky V (2008) Assembly, configuration, and break-up history of Rodinia: A synthesis. Precambrian Res. 160: 179-210.

Ludwig KR (2001) User manual for Isoplot/Ex rev. 2.49. A geochronological toolkit for Microsoft Excel. Berkeley Geochronology Center, Special Publication 1: 56 pp.

McDonough WF, Sun S-S (1995) The composition of the Earth. Chem. Geol. 120: 223-253.

Maniar PD, Piccoli, PM (1989) Tectonic discrimination of granitoids. Geol. Soc. Am. Bull. 101:635-643.

Meert JG (2003) A synopsis of events related to the assembly of eastern Gondwana. Tectonophysics 362: 1-40.

Mehnert K R (1968) Migmatites and the Origin of Granitic Rocks. Elsevier Sci., New York: $393 \mathrm{pp}$.

Mercolli I, Briner AP, Frei R, Schonberg R, Nägler, TF, Kramers J, Peters T (2006) Lithostratigraphy and geochronology of the Neoproterozoic crystalline basement of Salalah, Dhofar, Sultanate of Oman. Precambrian Res. 145: 182-206. 
Muhongo S, Lenoir J-L (1994) Pan-African granulite-facies metamorphism in the Mozambique belt of Tanzania: U-Pb zircon geochronology. J. Geol. Soc. Lond. 151, 343347.

Nehlig E, Genna A, Asfirane, E (2002) A review of the Pan-African evolution of the Arabian Shield. GeoArabia 7: 103-124.

Pearce JA, Harris BW, Tindle AG (1984) Trace element discrimination diagrams for the tectonic interpretation of granitic rocks. J. Petrol. 25: 956-983.

Razin P, Leroy S, Robin C, Robinet J, Serra Kiel J, Bellahsen N, Grelaud C (2010) Dispositifs tecto-sédimentaires syn-rift et post-rift Oligo-Miocènes sur la marge sud du Golfe d'Aden. Paper presented at the RST, Bordeaux, octobre 2010.

Saint Blanquat (de) M, Horsman E, Habert G, Morgan S, Vanderhaeghe O, Law R, Tikoff B (2010) Multiscale magmatic cyclicity, duration of pluton construction, and the paradoxical relationship between tectonism and plutonism in continental arcs. Tectonophysics: doi:10.1016/j.tecto.2009.12.009.

Shackleton RM (1996) The final collision zone between East and West Gondwana: Where is it? J. Afric. Earth Sci. 23: 271-287.

Stern RJ (1994) Arc Assembly and Continental Collision in the Neoproterozoic East-African Orogen-implications for the consolidation of Gondwanaland. Ann. Rev. Earth Planet. Sci. 22: 319-351.

Sun S-S, McDonough WF (1989) Chemical and isotopic systematics of ocean basalts: implications for mantle composition and process. In: Saunders AD, Norry MJ (eds.) Magmatism in the Ocean Basins. Spec. Pub. Geol. Soc. Lond. 42: 313-345.

Torsvik TH, Carter LM, Ashwal LD, Bhushan SK, Pandit MK, Jamtveit B (2001a) Rodinia refined or obscured: palaeomagnetism of the Malani igneous suite (NW India). Precambrian Res. 108: 319-333.

Torsvik TH, Ashwal LD, Tucker RD, Eide EA (2001b) Neoproterozoic geochronology and palaeogeography of the Seychelles microcontinent: the India link. Precambrian Res. 110: $47-59$.

Tucker RD, Ashwal LD, Hancke MJ, Hamilton MA, Le Grange M, Rambeloson, RA (1999a) $\mathrm{U}-\mathrm{Pb}$ geochronology and isotope geochemistry of the Archean and Proterozoic rocks of north-central Madagascar. J. Geol. 107: 135-153. 
Tucker RD, Ashwal LD, Torsvik TH (1999b) Neoproterozoic silicic magmatism in northern Madagascar, Seychelles and NW India: clues to Neoproterozoic supercontinent formation and dispersal. EOS Transactions, Am. Geophys. Union 80: 372-373.

Tucker RD, Ashwal LD, Torsvik TH (2001) U-Pb geochronology of Seychelles granitoids: a Neoproterozoic continental arc fragment. Earth Planet. Sci. Lett. 187: 27-38.

Whalen JB, Currie KL, Chappell BW (1987) A-Type granites: Geochemical characteristics, discrimination and petrogenesis. Contrib. Mineral. Petrol. 95:407-419.

Whitehouse MJ, Windley BF, Ba-bttat MAO., Fanning CM, Rex DC (1998) Crustal evolution and terrane correlation in the eastern Arabian Shield, Yemen: geochronological constraints. J. Geol. Soc. Lond. 155: 281-295.

Whitehouse MJ, Windley BF, Stoeser DB, Al-Khirbash S, Ba-Bttat MAO, Haider A (2001) Precambrian basement character of Yemen and correlations with Saudi Arabia and Somalia. Precambrian Res. 105: 357-369.

Whitney DL, Evans B (2010) Abbrevations for names of rock-forming minerals. Am. Mineralogist 95: 185-187.

\section{Figure caption}

Fig. 1: a) Reconstitution of the late Neoproterozoic EAAO (modified from Jacobs and Thomas, 2004). Abbreviations: $\mathrm{EF}=$ European fragments, $\mathrm{M}=$ Madagascar, $\mathrm{S}=$ hypothesis for the paleoposition of the Socotra Island at the end of the Neoproterozoic. b) Geological map of the Arabian-Nubian Schield (modified from Whitehouse et al., 1998, Nelhig et al., 2002; Jonhson and Woldehaimot, 2003).

Fig. 2: Geological and topographic map of Socotra. Topographic contours have been realized by using the SRTM data (2001). Oligo-Miocene structures are from Razin et al. (2010).

Fig. 3: Detailed geological map of the Sherubrub area.

Fig. 4: Field photographs, microphotographs (scale bar $=2 \mathrm{~mm}$ ); a) Ortho-amphibolitic boudins in white quartzites (Sherubrub area); b) Bt+Sil+Afs \pm And (see Whitney and Evans, 
2010 for mineral abbreviations) paragenesis in migmatitic paragneiss (metatexite) at the contact between leucosom and melanosom (plane polarized light); c) Gabbro metamorphised in the amphibolite-facies (planar polarized light, Mont Haggier area); d) Pyroclastic basaltic breccia; e) Basaltic tuff with breccia levels (planar polarized light); f) Intrusive contact of the Haggier pink granite in the doleritic basalt SP15A.

Fig. 5: A: Geological transect representing the studied area which correspond to a single bank and location of the photographs B. B = Field photographs or microphotographs (scale bar = $2 \mathrm{~mm}$ ) or field sketch: a) Hornblende-bearing medium-grained diorites with stretching lineation; b) Schematic illustration of microphotograph a; c) Alternating of sheets of tonalites and diorites; d) Straight contact between tonalites and granodiorites; e) Mingling between dioritic and granodioritic magmas; f) Vertical stretching lineation in diorites.

Fig. 6: Field photographs or microphotographs (scale bar $=2 \mathrm{~mm}$ ): a) Haggier layered gabbro; b) $\mathrm{Cpx}+\mathrm{Pl}+\mathrm{O} 1$ layered gabbro (planar polarized light, Mont Haggier area); c) Intrusion of granodiorites sills in the Sherubrub gabbros; d) Schematic illustration of photograph c.

Fig. 7: Field photographs or microphotographs (scale bar $=2 \mathrm{~mm}$ ): a) Sherubrub granite with weak sub-solidus deformation (as = automorphic sphene, crossed polars); b) Protomylonitic microstructure in Sherubrub granite (crossed polars); c) Amphibolitic rafts in pinkish Sherubrub granite; d) Pegmatite swarm in gabbros at the periphery of the Sherubrub granite; e) Quartz, zoned plagioclase and biotite in the Northern Haggier biotite granite (crossed polars); f) Texture of the Haggier pink granite (planar polarized light).

Fig. 8: Field photographs or microphotographs (scale bar $=2 \mathrm{~mm}$ ): a) Magmatic breccia with element of gabbro in Haggier pink granite matrix; b) Arfvedsonite (in blue) in the Haggier pink granite (planar polarized light); c) Chessboard texture in quartz of the Haggier pink granite (crossed polars); d) Basaltic dike intrusive in the Northern-Haggier Bt granite; e) Doleritic texture in basaltic dikes formed mainly by hornblende and plagioclase; f) Rhyolitic dikes intrusive in the Haggier layered gabbros.

Fig. 9: Stereogramms of dikes orientation in the Mont-Haggier area (Schmidt lower hemisphere), a) Dikes of pinkish microgranite (36 measurements), b) Rhyolitic dikes (33), g) Basaltic dikes (17). 
829 Fig. 10: Total alkali silica diagram (LeBas et al., 1986) for magmatic rocks from Socotra Island. For the Mont-Haggier samples squares represent the mafic lavas and dikes, circles represent the granites and the triangle correspond to the basalt SP15A.

833 Fig. 11: A and B. Patterns of mafic cumulates and related volcanic and subvolcanic rocks 834 from Mont-Haggier area normalised to Silicate Earth (McDonough and Sun, 1995) and 835 Chondrites (Sun and McDonough, 1989), respectively. C. Patterns of diorites from Qalansya

836 837 area and of the basalt SP15A from the Mont-Haggier area normalised to Silicate Earth (McDonough and Sun, 1995). D. Discrimination diagram (Cabanis and Lecolle, 1989) for subvolcanic to volcanic mafic rocks of Mont-Haggier area and the diorite of Qalantsya.

Fig. 12: A. ANK vs ACNK (Maniar and Piccoli, 1989) discrimination diagram for granitic bodies of Sherubrub area (grey circles) and Mont-Haggier area (dark circles). B. Patterns of granitic rocks from Socotra Island normalised to Silicate Earth (McDonough and Sun, 1995). C. $\mathrm{Zr}+\mathrm{Nb}+\mathrm{Y}+\mathrm{Ce}$ vs $1000 * \mathrm{Ga} / \mathrm{Al}$ diagram (Whalen et al., 1987) of granitic rocks from Socotra island. D. Discrimination diagram (Pearce et al., 1984) of granitic rocks from Socotra island.

Fig. 13: U-Pb concordia diagrams for (a) Haggier pink granite (sample HAEU-1), (b) gabbro enclaves in Haggier pink granite (sample HAEU-2) and (c) Sherubrub granite (sample SHEU$1)$.

Fig. 14: Interpretative block-diagram of the Mont-Haggier area.

Table 1: Major and trace elements compositions of selected magmatic rocks from Socotra island. $<$ D.L. below detection limit. $\mathrm{Mg} \#=100 \times \mathrm{MgO} /(\mathrm{MgO}+\mathrm{FeOT}$ otal $)$, on a molar basis.

Table 2: Analytic results of U-Pb dating using ion microprobe (CAMECA IMS 1270) on zircons from samples HAEU-1, HAEU-2 and SHEU-1.

.

.


862

863

864

865

866 

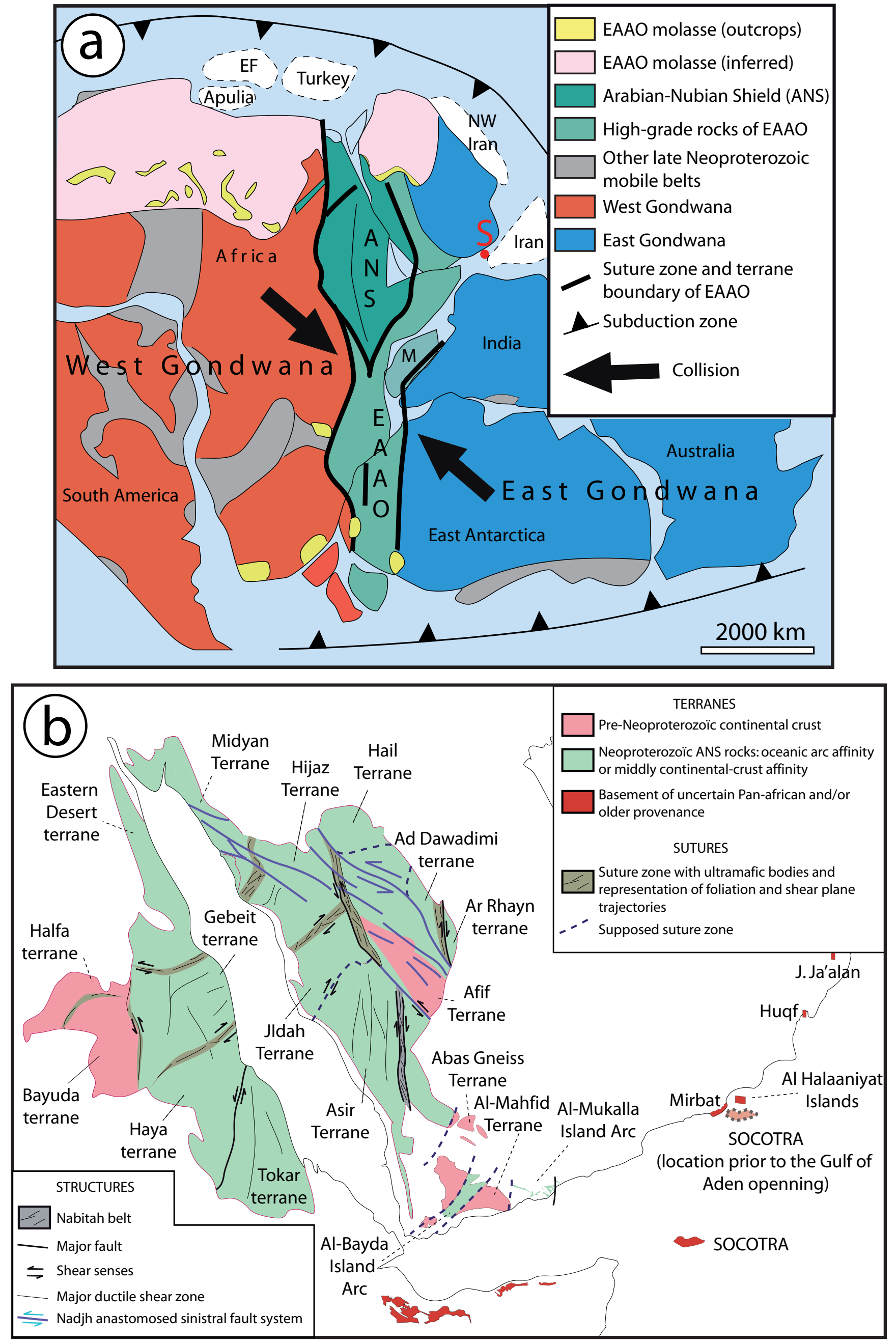


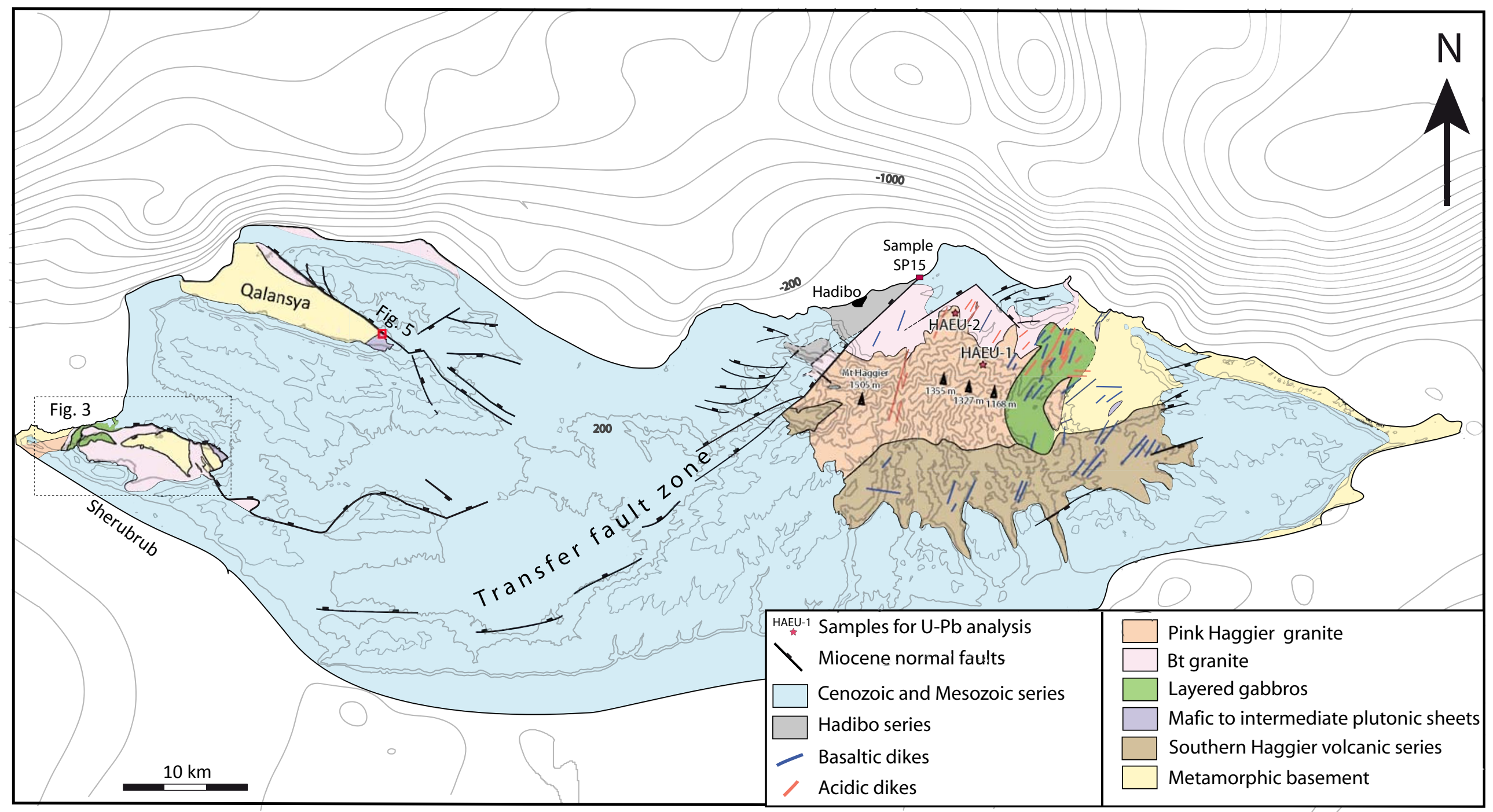




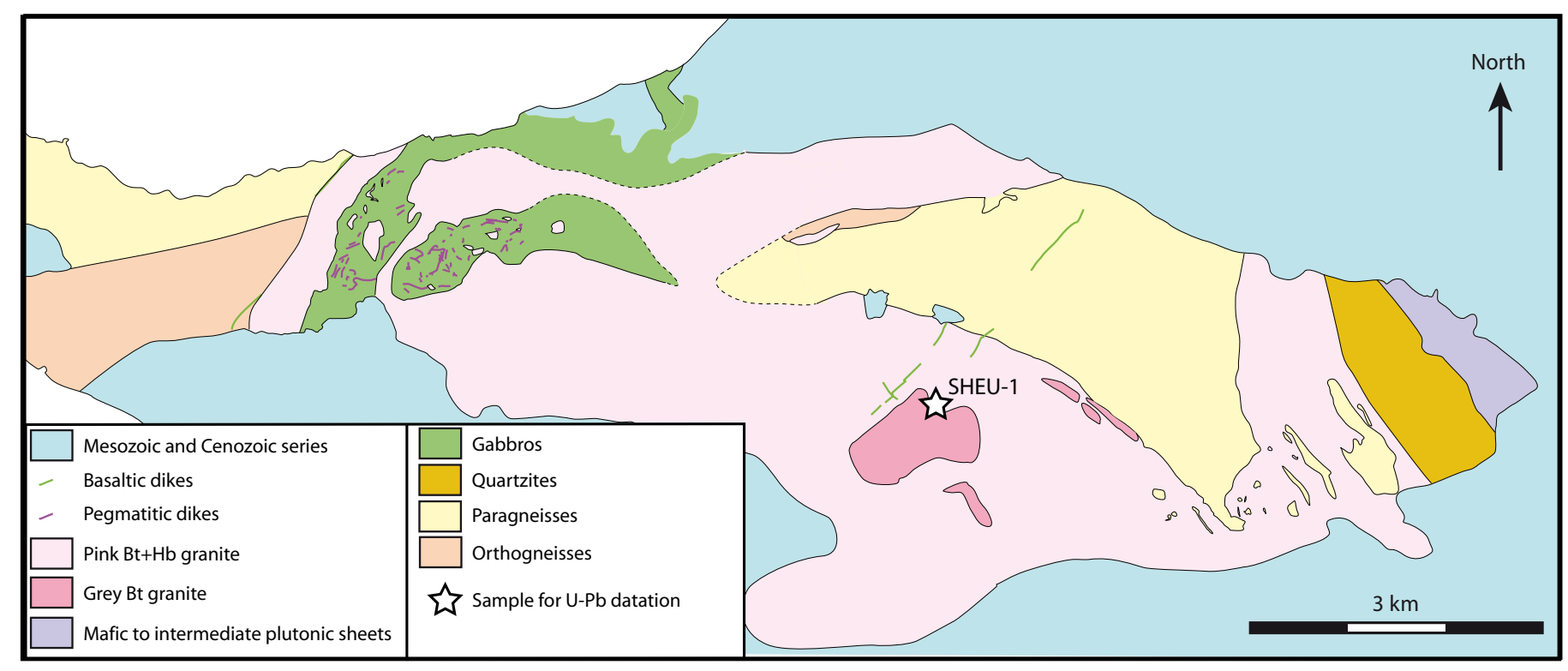



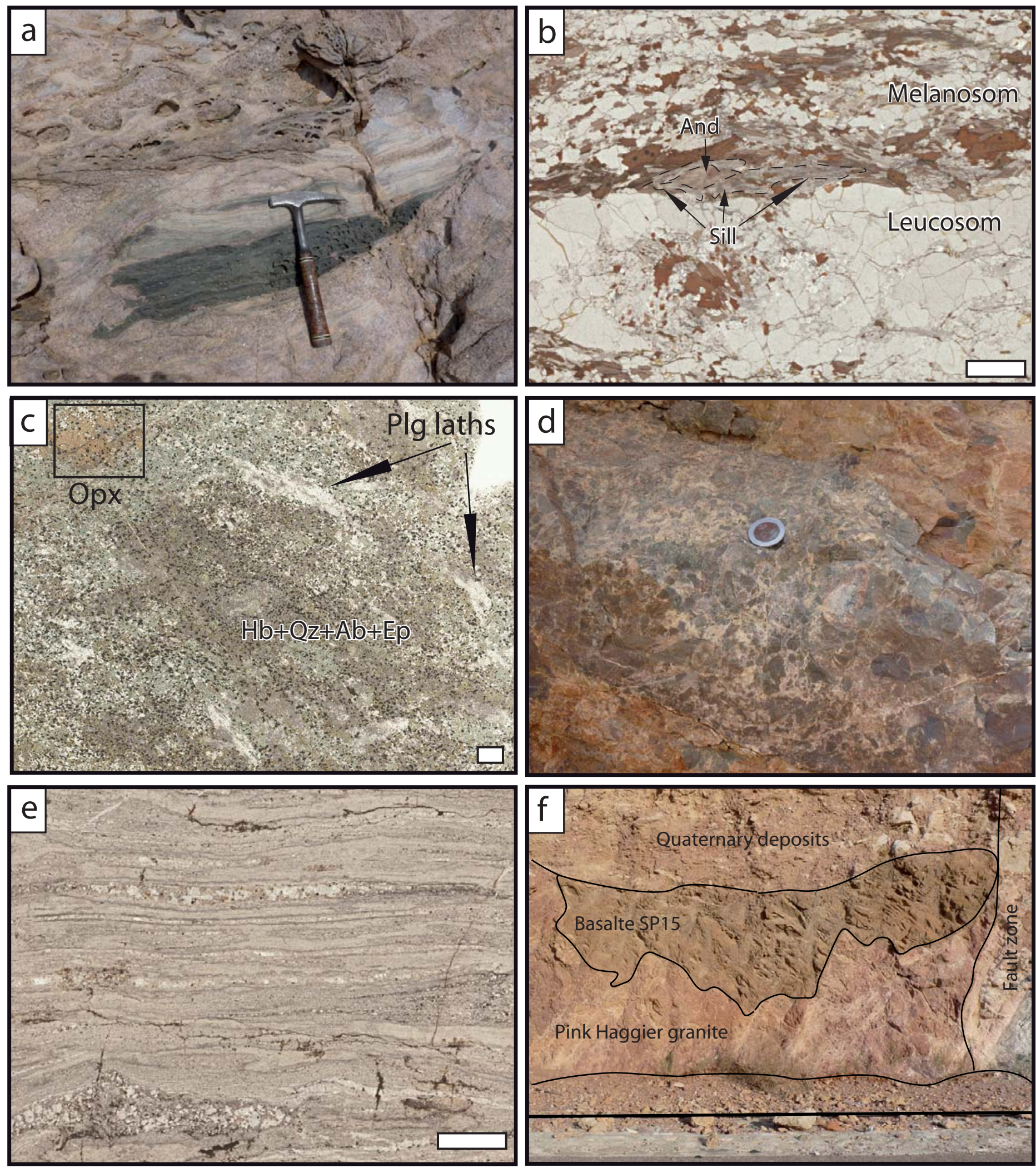
A

W-NW

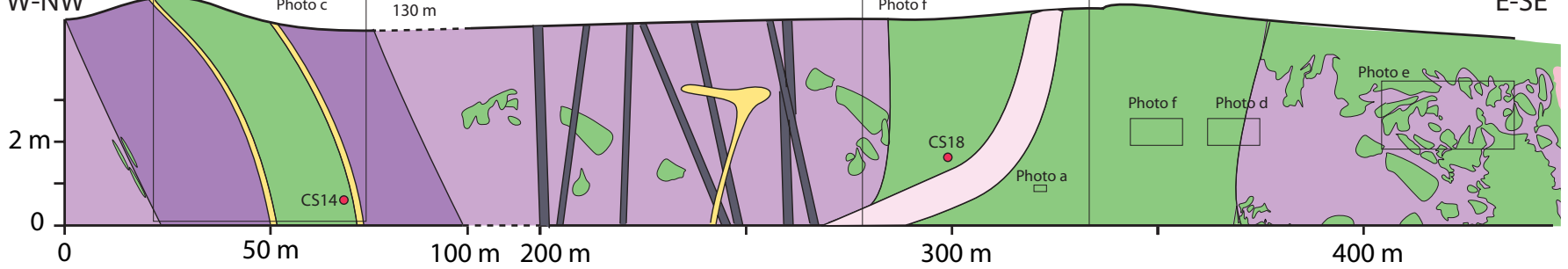

B - Basaltic dikes $\square$ Aplitic dike $\square$ Bt+Mu granite $\square$ Granodiorite $\square$ Tonalite $\square$ Gabbro • Sample number
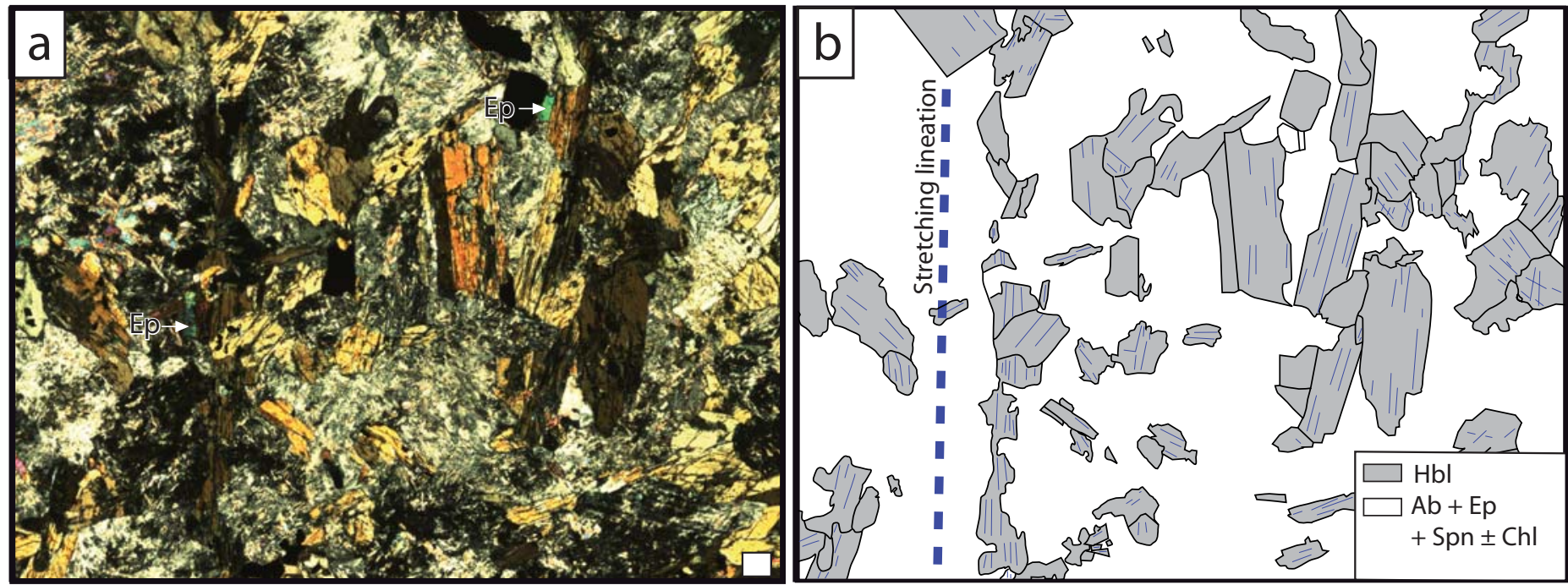

C
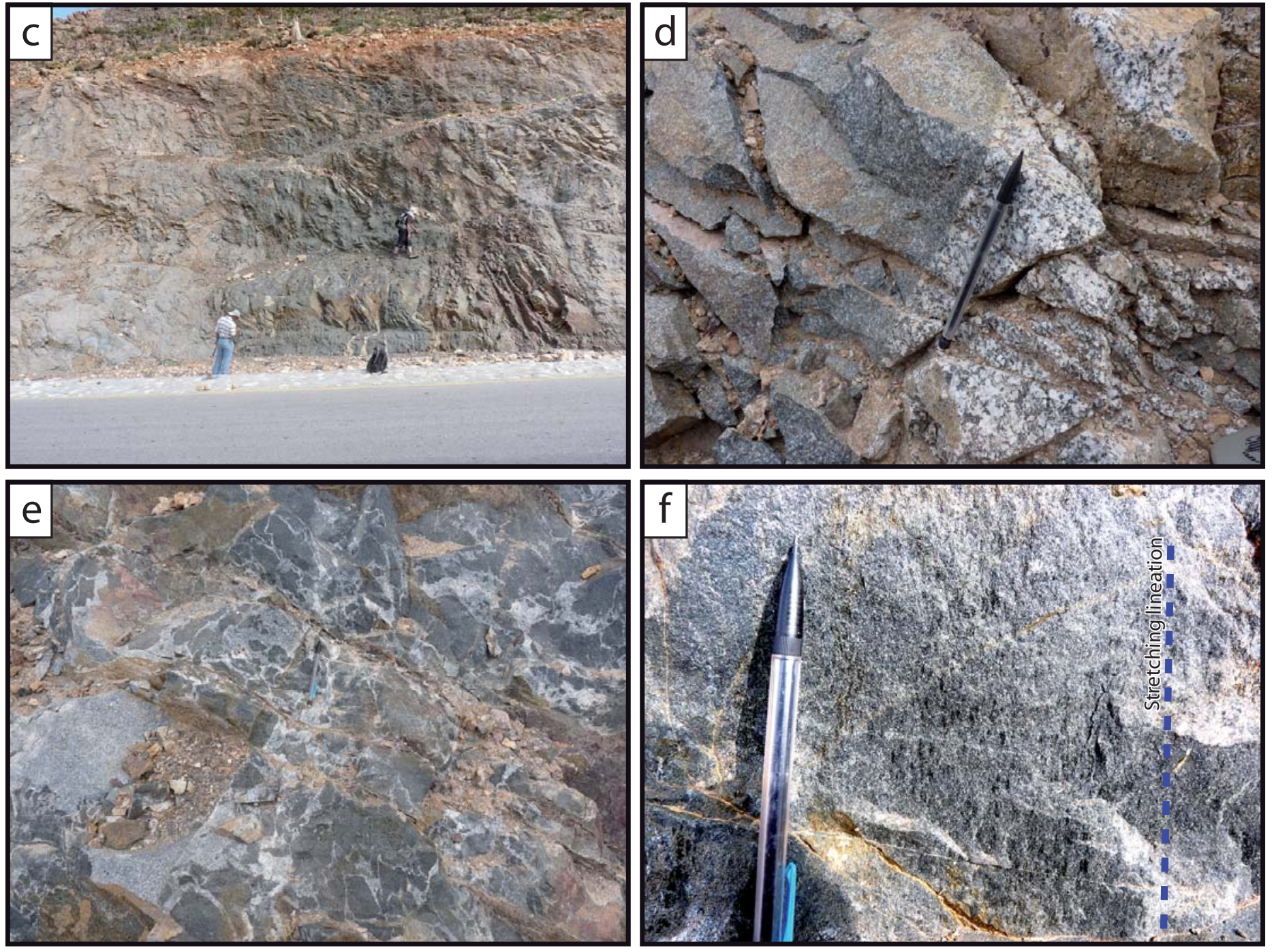

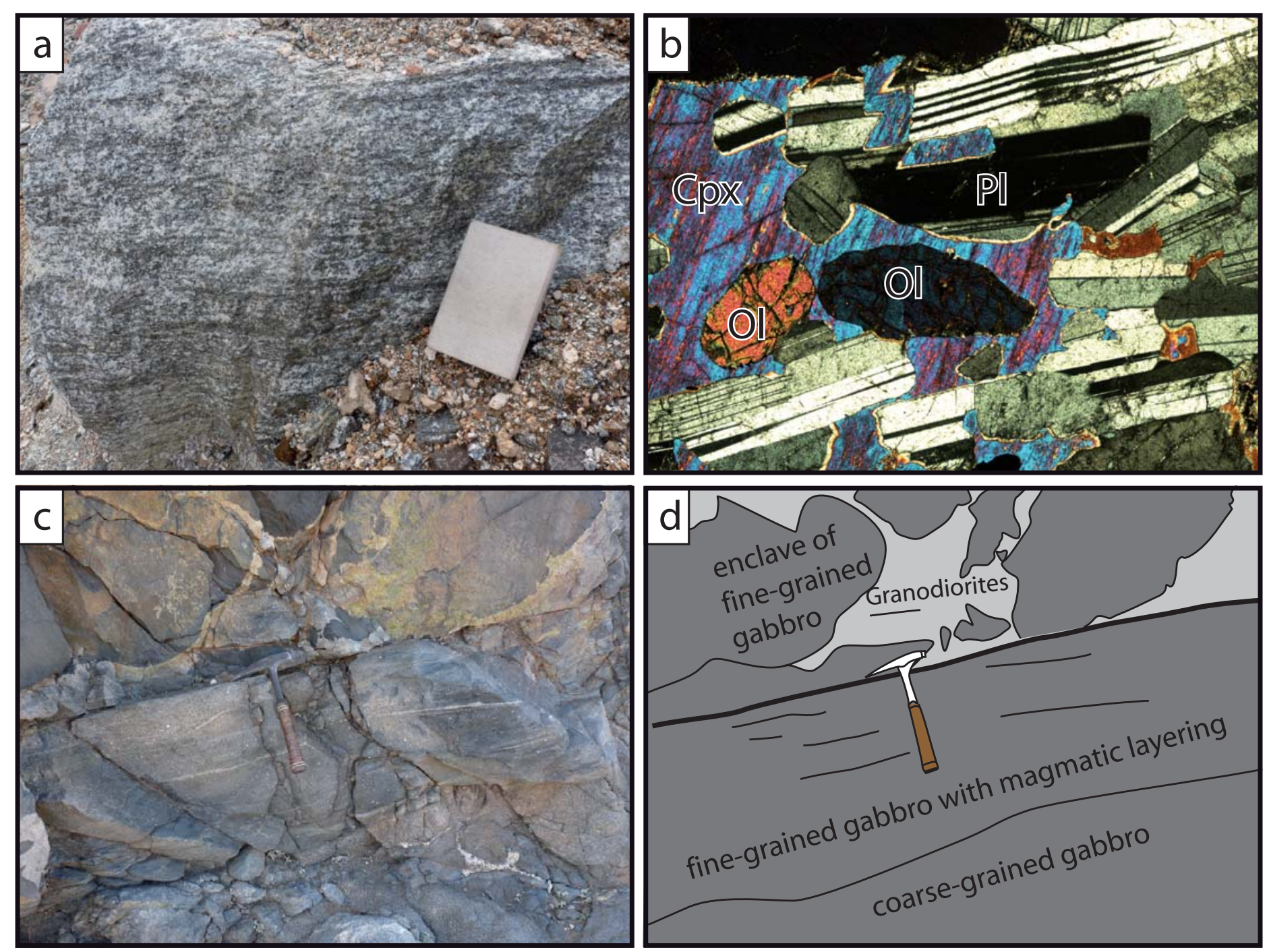

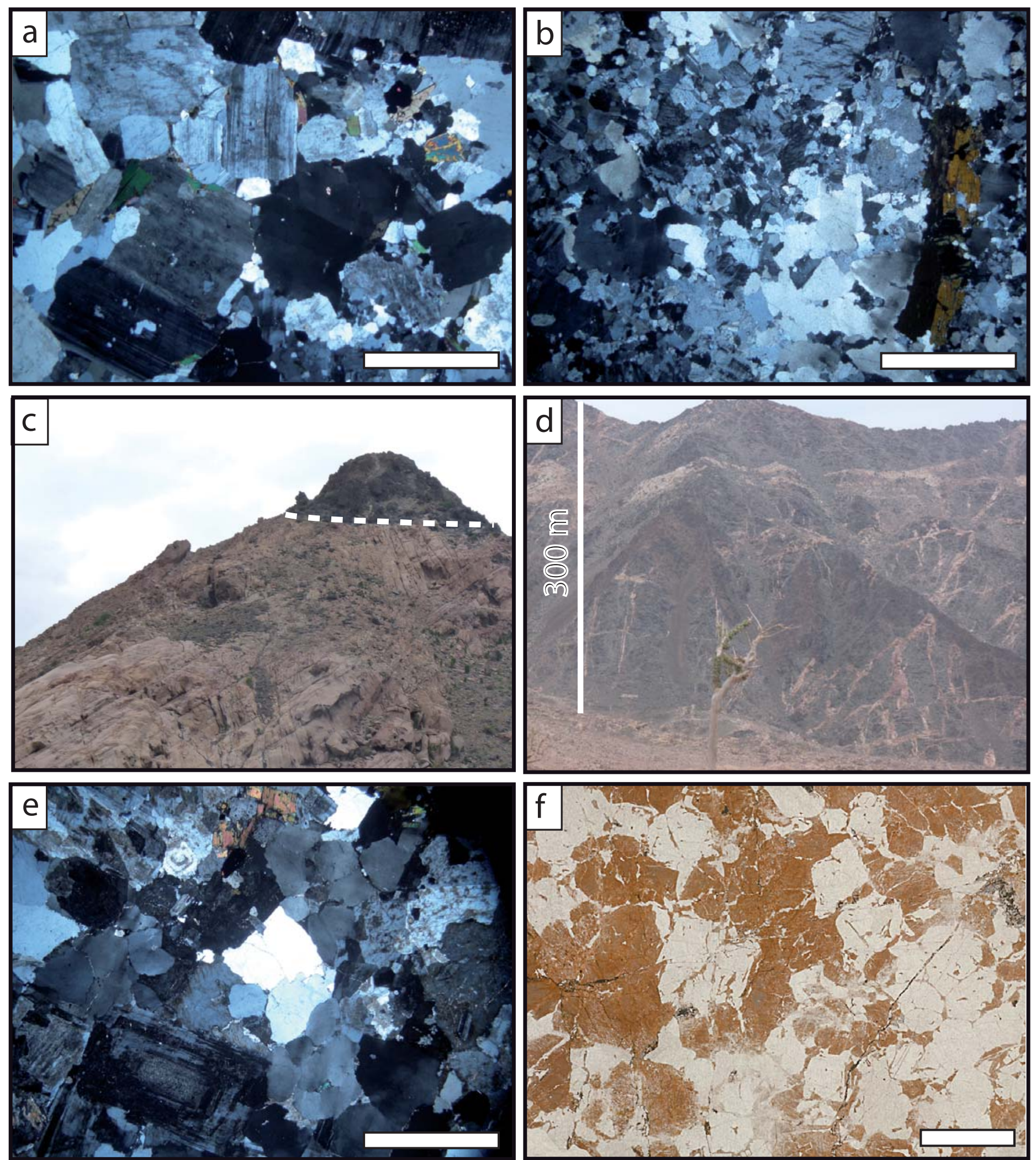

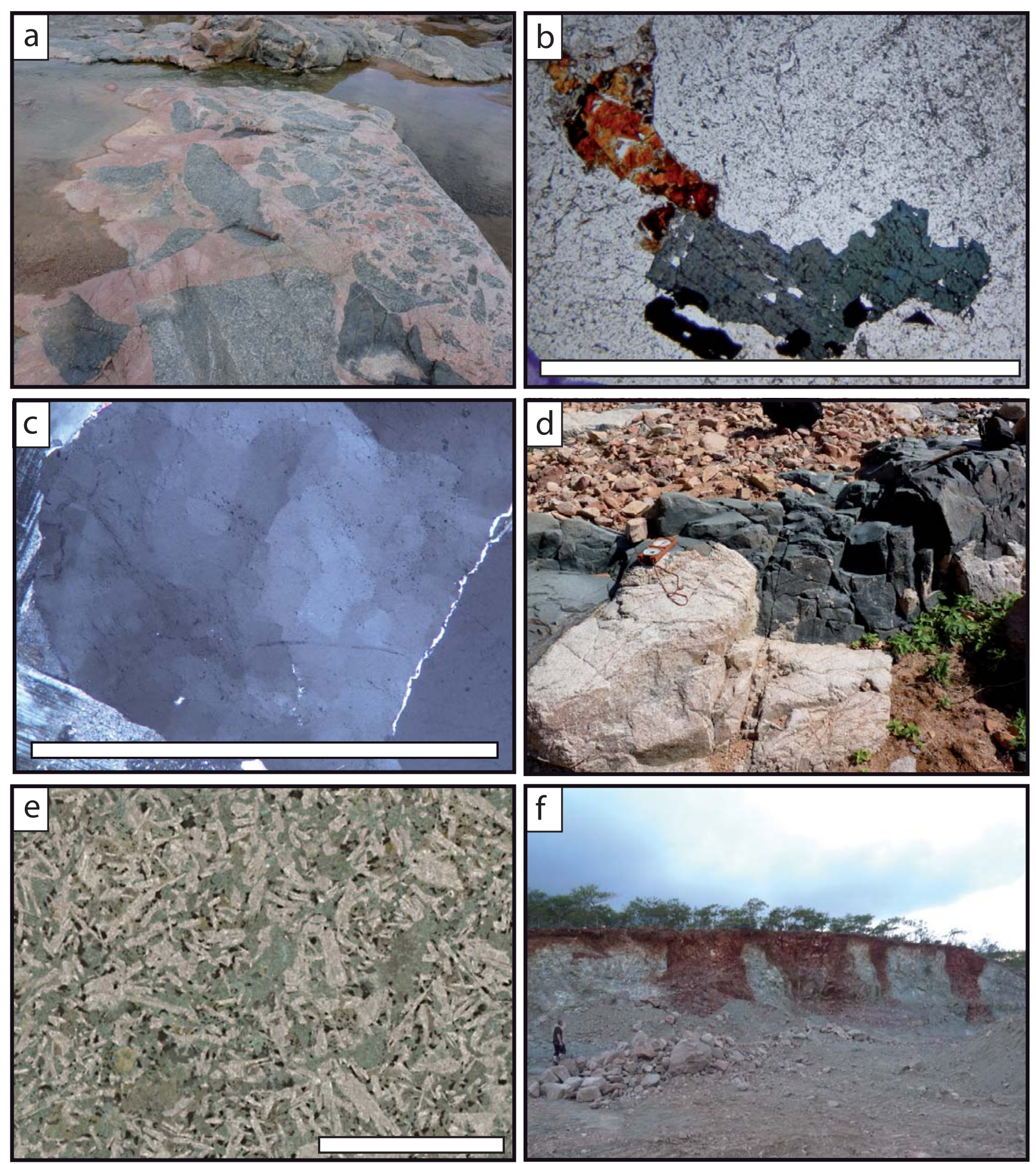


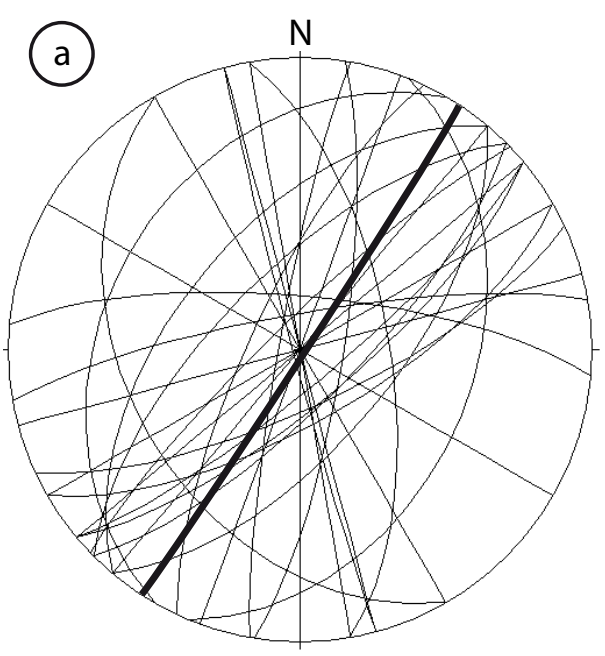

Mean plane $=\mathrm{N} 33^{\circ} \mathrm{E}, \mathrm{S} 89$

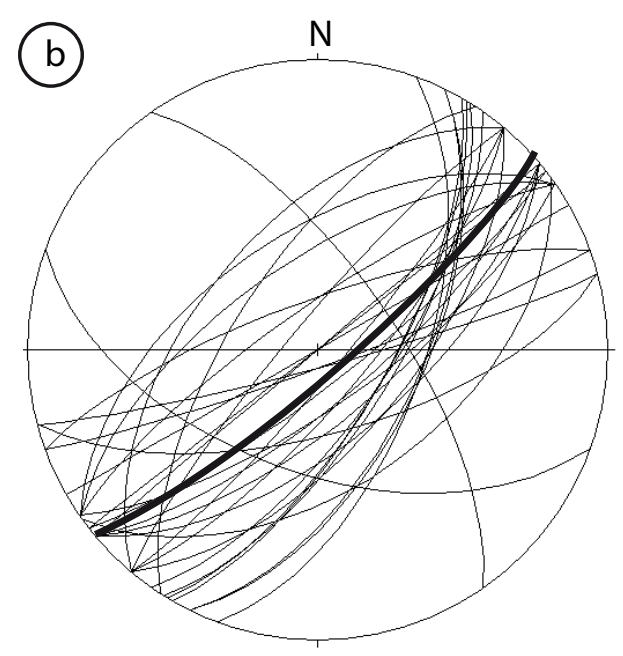

Mean plane $=\mathrm{N} 59^{\circ} \mathrm{E}, \mathrm{S} 81$

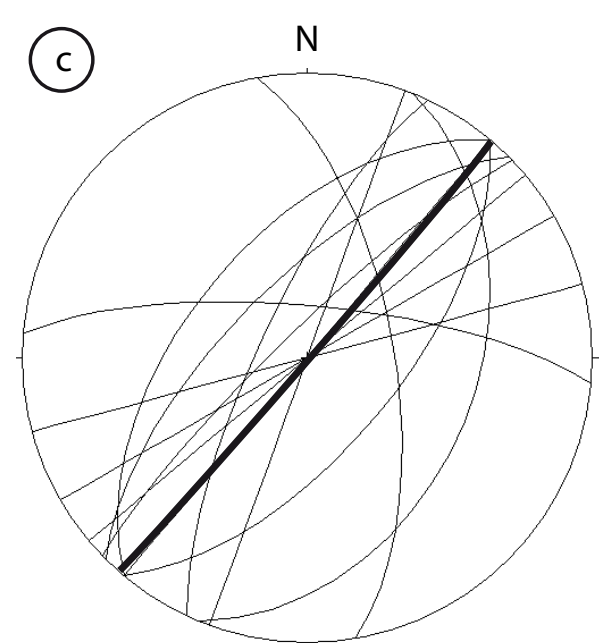

Mean plane $=\mathrm{N} 41^{\circ} \mathrm{E}, \mathrm{S} 89$ 


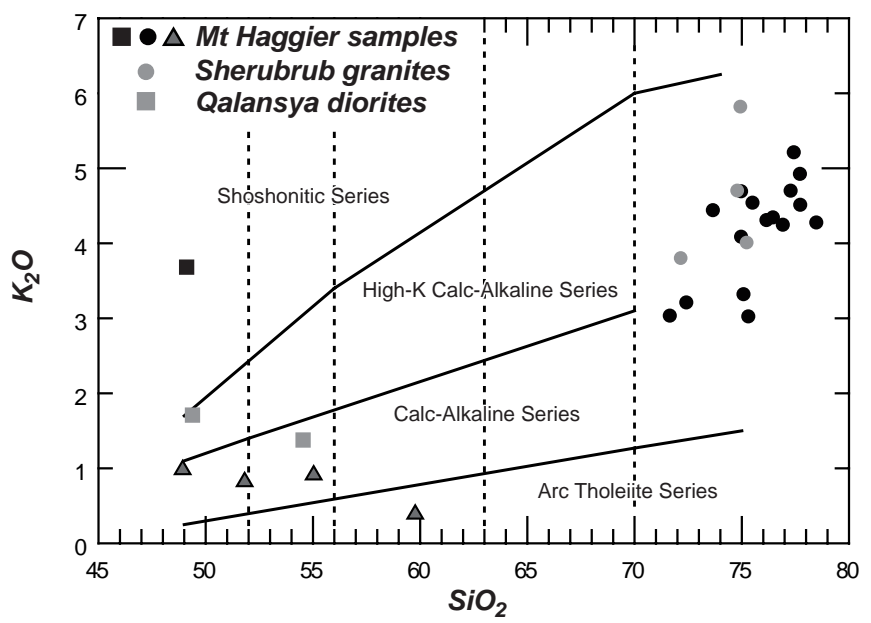



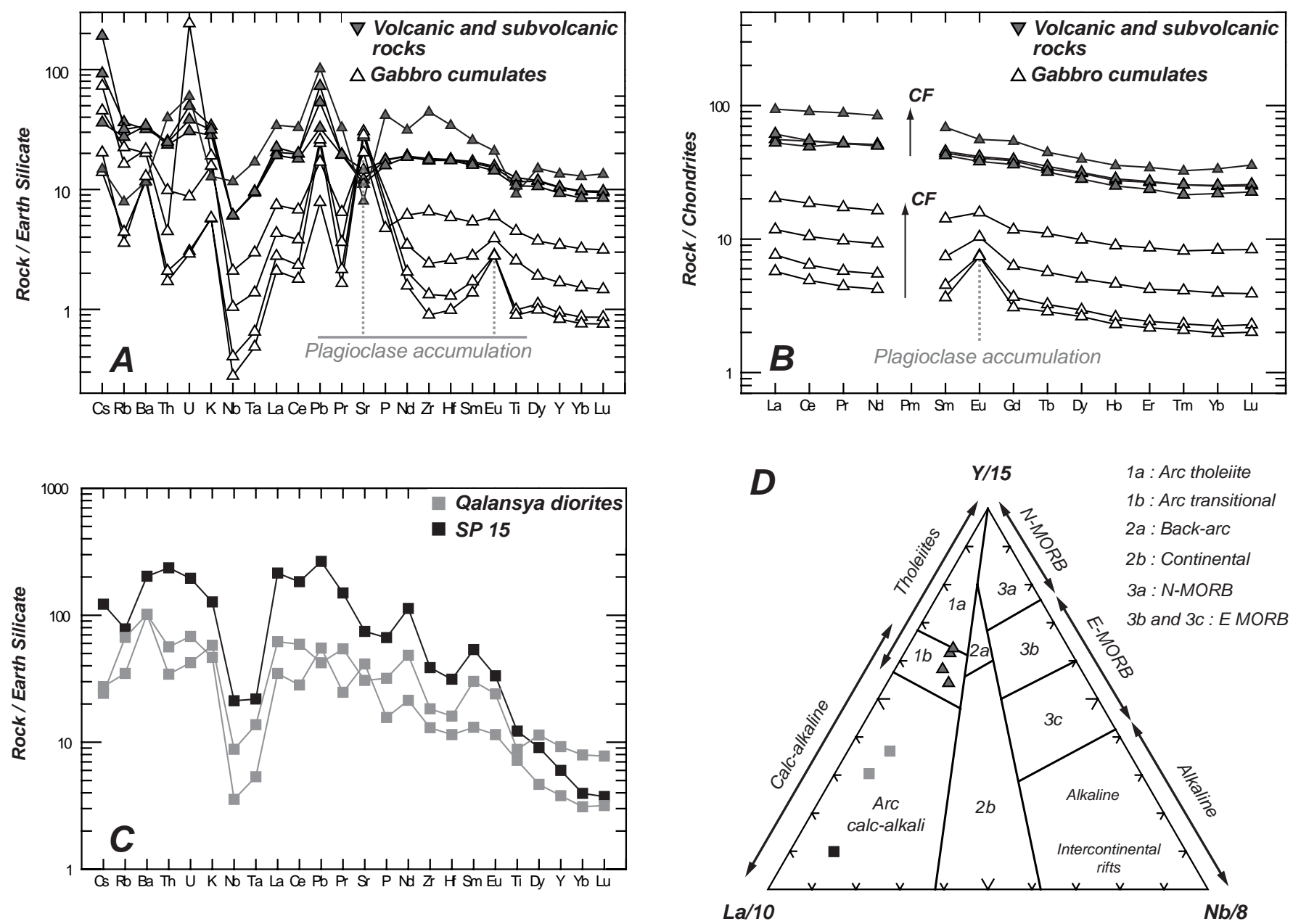

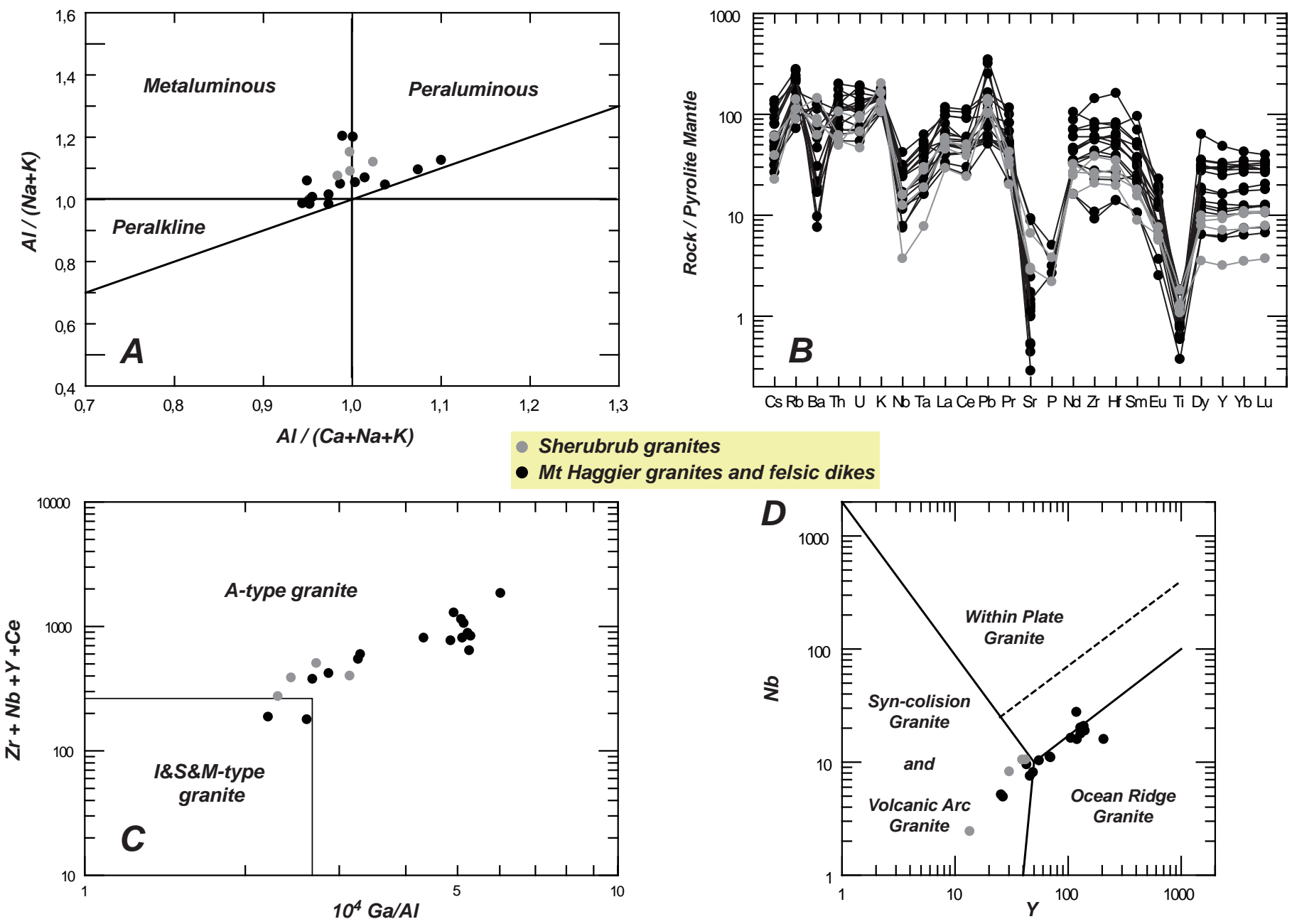

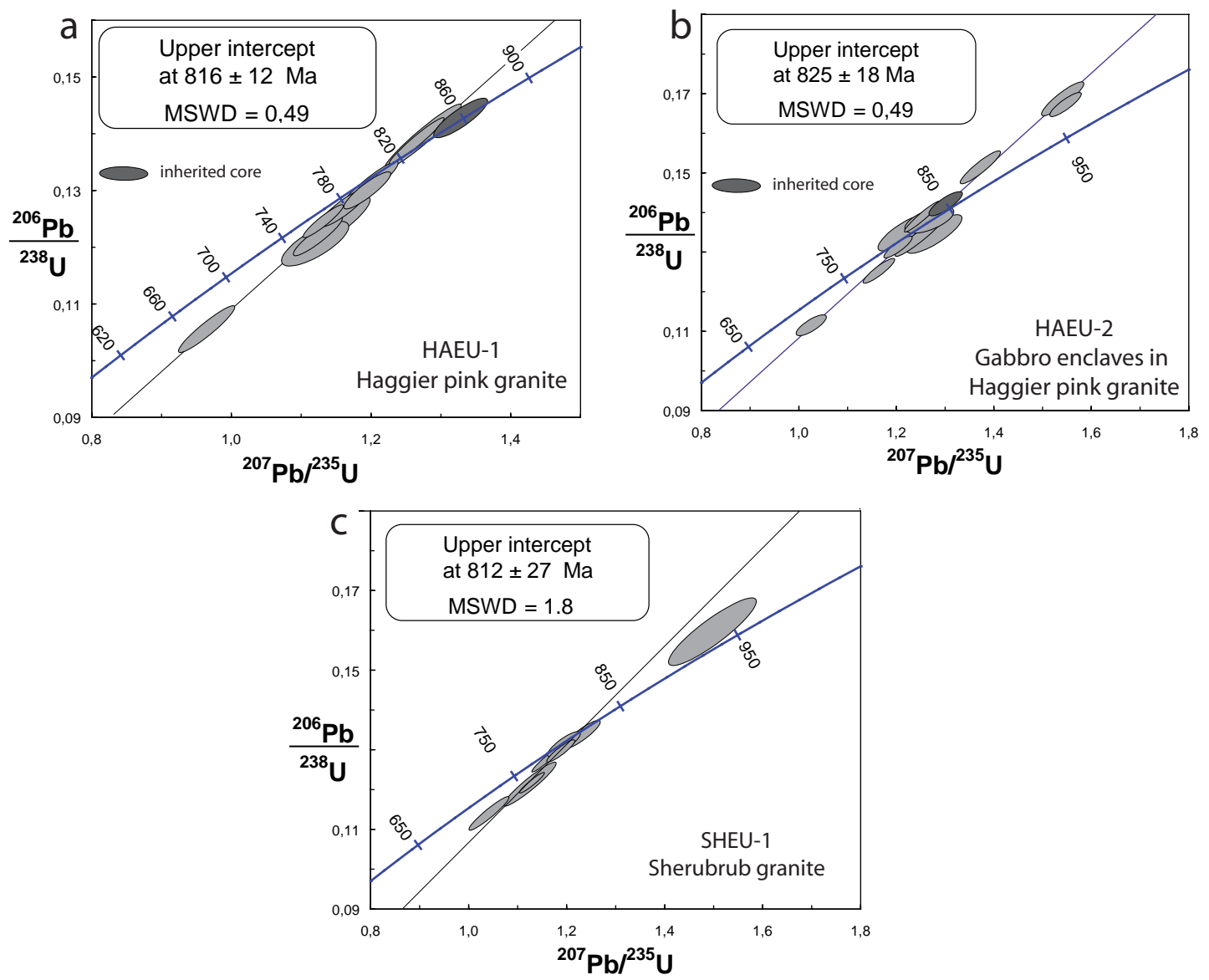


\section{- Tertiary fault zones}

Cenozoic and Mesozoic series

Hadibo series

Acidic dikes

Haggier pink granite

Northern-Haggier Bt granite

Basaltic dikes

Southern volcanic series

Haggier layered gabbros with magmatic layering

Metamorphic basement with foliation trajectories

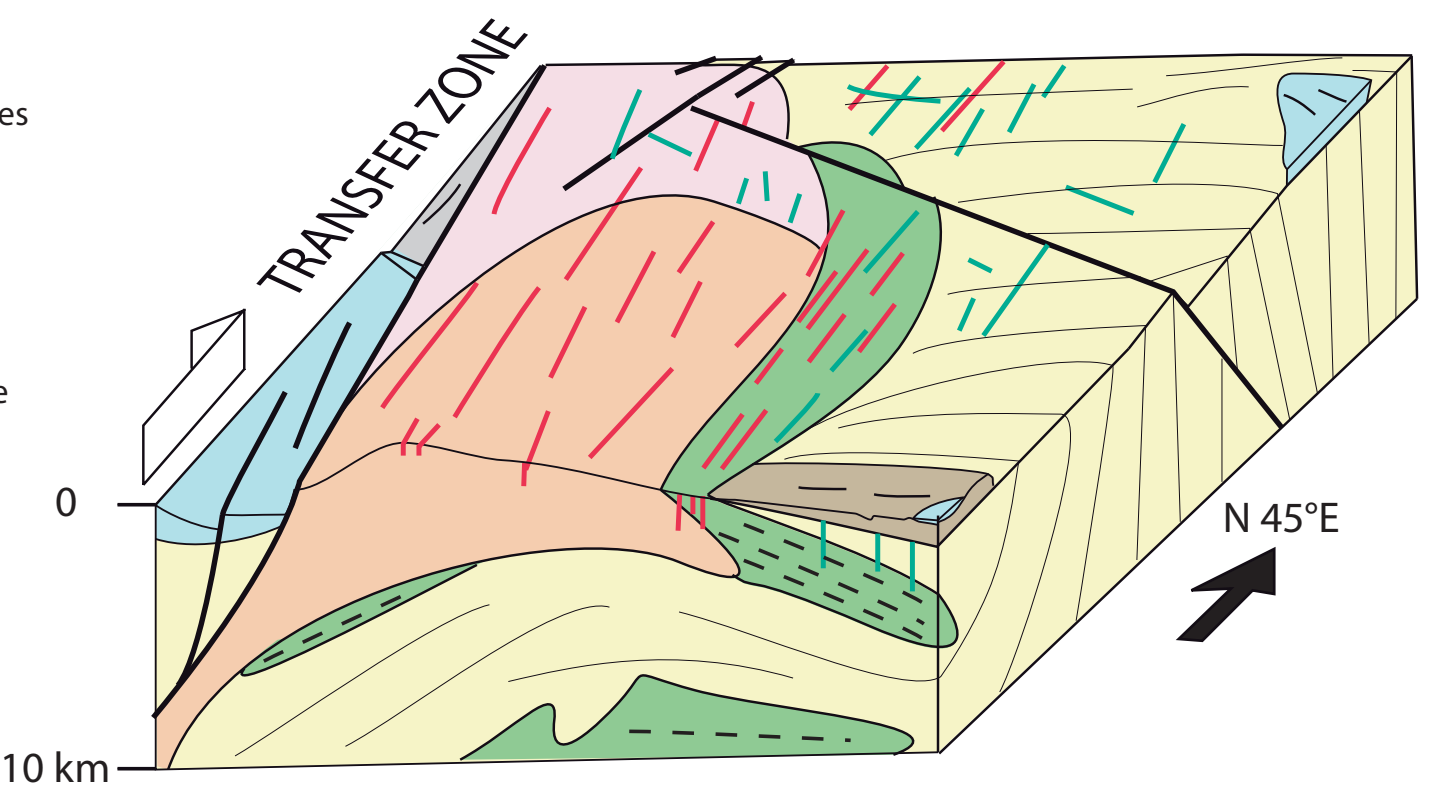




\begin{tabular}{|c|c|c|c|c|c|c|c|c|c|c|c|c|c|c|c|}
\hline Sample & SP10 & SP16B & SP18 & S20 & S1 & CS48A & S2 & S5 & SP15A & CS14A & CS18A & SP3 & SP8B & CS45B & CS1A \\
\hline Location & Haggier & Haggier & Haggier & $\begin{array}{l}\text { Haggier } \\
\text { Basaltic }\end{array}$ & Haggier & Haggier & $\begin{array}{l}\text { Haggier } \\
\text { Gabbro }\end{array}$ & $\begin{array}{l}\text { Haggier } \\
\text { Gabbro }\end{array}$ & $\begin{array}{l}\text { Haggier } \\
\text { Altered }\end{array}$ & Qalansya & Qalansya & Haggier & Haggier & Haggier & Haggier \\
\hline Litionigy & IVialic uike & Midic tuin & Midilic Gike & lava & Cuminale & cumulate & & & basalt & Diorites & Diorites & Bt Granite & Bt Granite & Bt Granite & Bt Granite \\
\hline \multicolumn{16}{|l|}{$\%$} \\
\hline $\mathrm{SiO} 2$ & 48.92 & 55.04 & 51.82 & 59.86 & 48.09 & 50.94 & 49.63 & 51.10 & 49.11 & 49.38 & 54.55 & 71.67 & 75.11 & 73.68 & 72.45 \\
\hline $\mathrm{Al} 2 \mathrm{O} 3$ & 14.31 & 13.52 & 14.60 & 10.64 & 26.32 & 23.26 & 21.08 & 17.30 & 15.31 & 16.94 & 17.21 & 13.89 & 12.88 & 11.72 & 14.34 \\
\hline $\mathrm{Fe} 2 \mathrm{O} 3 \mathrm{t}$ & 13.03 & 11.59 & 13.99 & 11.21 & 2.71 & 4.10 & 5.53 & 7.80 & 8.86 & 11.15 & 8.48 & 2.15 & 1.99 & 3.47 & 1.90 \\
\hline $\mathrm{MnO}$ & 0.32 & 0.26 & 0.25 & 0.24 & 0.04 & 0.06 & 0.08 & 0.13 & 0.13 & 0.20 & 0.13 & 0.11 & 0.07 & 0.07 & 0.08 \\
\hline $\mathrm{MgO}$ & 2.86 & 2.43 & 3.07 & 2.89 & 3.70 & 3.66 & 7.55 & 6.72 & 3.15 & 4.08 & 4.40 & 0.53 & 0.08 & 0.05 & 0.43 \\
\hline $\mathrm{CaO}$ & 8.33 & 6.42 & 6.69 & 5.20 & 14.78 & 12.78 & 11.95 & 10.68 & 6.01 & 6.92 & 7.33 & 1.27 & 0.34 & 0.29 & 1.42 \\
\hline $\mathrm{Na} 2 \mathrm{O}$ & 3.61 & 4.06 & 3.86 & 2.66 & 2.13 & 2.70 & 2.81 & 3.02 & 4.05 & 4.48 & 4.36 & 5.04 & 5.25 & 4.31 & 5.14 \\
\hline K2O & 0.98 & 0.91 & 0.82 & 0.37 & 0.17 & 0.55 & 0.17 & 0.45 & 3.68 & 1.68 & 1.35 & 3.03 & 3.31 & 4.43 & 3.20 \\
\hline TiO2 & 2.33 & 2.15 & 2.52 & 1.86 & 0.20 & 0.51 & 0.18 & 0.90 & 2.46 & 1.76 & 1.45 & 0.37 & 0.16 & 0.25 & 0.36 \\
\hline P2O5 & 0.37 & 0.33 & 0.36 & 0.86 & $<$ D.L. & $<$ D.L. & < D.L. & 0.10 & 1.37 & 0.66 & 0.32 & 0.10 & 0.06 & $<$ D.L. & 0.07 \\
\hline LOI & 3.76 & 3.17 & 1.37 & 3.40 & 1.20 & 1.55 & 1.44 & 1.37 & 5.99 & 2.01 & 0.98 & 0.67 & 0.29 & 0.41 & 0.66 \\
\hline Total & 98.82 & 99.88 & 99.35 & 99.18 & 99.34 & 100.11 & 100.41 & 99.57 & 100.13 & 99.26 & 100.55 & 98.83 & 99.55 & 98.68 & 100.03 \\
\hline \multicolumn{16}{|l|}{ ppm } \\
\hline As & 3 & 3 & 4 & 2 & $<$ D.L. & $<$ D.L. & $<$ D.L. & $<$ D.L. & 4 & $<$ D.L. & $<$ D.L. & $<$ D.L. & $<$ D.L. & 2 & $<$ D.L. \\
\hline $\mathrm{Ba}$ & 210 & 225 & 224 & 76 & 77 & 133 & 85 & 142 & 1338 & 670 & 669 & 821 & 816 & 307 & 744 \\
\hline $\mathrm{Be}$ & 1.4 & < D.L. & $<$ D.L. & 2.6 & < D.L. & $<$ D.L. & $<$ D.L. & 0.5 & 2.7 & 1.4 & 1.0 & 2.3 & 2.3 & 8.1 & 2.3 \\
\hline $\mathrm{Bi}$ & $<$ D.L. & $<$ D.L. & $<$ D.L. & < D.L. & $<$ D.L. & $<$ D.L. & $<$ D.L. & $<$ D.L. & $<$ D.L. & $<$ D.L. & $<$ D.L. & $<$ D.L. & $<$ D.L. & 0.4 & $<$ D.L. \\
\hline $\mathrm{Cd}$ & 0.3 & $<$ D.L. & 0.2 & 0.2 & $<$ D.L. & 0.1 & 0.1 & $<$ D.L. & 0.2 & $<$ D.L. & 0.2 & $<$ D.L. & 0.2 & 0.7 & $<$ D.L. \\
\hline Co & 27.7 & 23.5 & 28.5 & 16.4 & 15.0 & 18.2 & 40.5 & 38.1 & 21.3 & 24.7 & 25.2 & 1.5 & 0.7 & $<$ D.L. & 1.4 \\
\hline $\mathrm{Cr}$ & 18 & 15 & 18 & 0 & 211 & 88 & 165 & 123 & 27 & $<$ D.L. & 52 & 6 & 6 & 4 & 6 \\
\hline Cs & 1.9 & 4.0 & 0.8 & 0.3 & 0.3 & 1.0 & 0.4 & 1.5 & 2.6 & 0.5 & 0.6 & 1.0 & 0.7 & 1.1 & 1.3 \\
\hline $\mathrm{Cu}$ & 29 & 12 & 23 & 8 & 38 & 24 & 108 & 78 & 61 & 154 & 55 & $<$ D.L. & $<$ D.L. & 26 & 17 \\
\hline Ga & 20.4 & 19.4 & 24.1 & 23.2 & 18.5 & 18.5 & 16.6 & 18.5 & 25.8 & 20.4 & 20.6 & 21.1 & 22.2 & 31.9 & 20.3 \\
\hline $\mathrm{Ge}$ & 1.7 & 1.5 & 1.9 & 2.6 & 0.9 & 1.0 & 0.9 & 1.3 & 1.6 & 1.4 & 1.2 & 1.7 & 1.8 & 2.4 & 1.7 \\
\hline $\mathrm{Hf}$ & 4.99 & 4.88 & 4.97 & 9.65 & 0.36 & 0.72 & 0.28 & 1.64 & 8.77 & 4.49 & 3.21 & 7.47 & 10.35 & 21.28 & 6.29 \\
\hline In & 0.10 & < D.L. & 0.11 & < D.L. & $<$ D.L. & $<$ D.L. & $<$ D.L. & $<$ D.L. & $<$ D.L. & $<$ D.L. & $<$ D.L. & $<$ D.L. & 0.12 & 0.25 & $<$ D.L. \\
\hline Mo & 0.8 & 0.7 & 1.1 & 0.6 & 0.6 & 2.9 & 0.0 & 0.4 & 0.6 & 0.7 & 0.4 & 0.4 & 0.6 & 1.5 & 0.7 \\
\hline $\mathrm{Nb}$ & 4.0 & 4.0 & 4.0 & 7.7 & 0.3 & 0.7 & 0.2 & 1.4 & 14.0 & 5.8 & 2.3 & 9.5 & 7.5 & 27.6 & 10.3 \\
\hline $\mathrm{Ni}$ & 10 & 8 & 7 & < D.L. & 73 & 30 & 122 & 50 & 16 & $<$ D.L. & 35 & < D.L. & $<$ D.L. & $<$ D.L. & < D.L. \\
\hline $\mathrm{Pb}$ & 8 & 11 & 5 & 15 & 4 & 4 & 1 & 3 & 40 & 6 & 8 & 9 & 8 & 52 & 11 \\
\hline $\mathrm{Rb}$ & 22 & 19 & 16 & 5 & 3 & 13 & 2 & 10 & 47 & 40 & 21 & 56 & 55 & 104 & 66 \\
\hline $\mathrm{Sb}$ & 0.2 & 0.7 & 0.2 & 0.8 & $<$ D.L. & 0.1 & $<$ D.L. & $<$ D.L. & 0.4 & $<$ D.L. & $<$ D.L. & $<$ D.L. & $<$ D.L. & 0.5 & 0.1 \\
\hline Sn & 2.1 & 1.7 & 2.0 & 2.4 & $<$ D.L. & 1.0 & $<$ D.L. & 0.6 & 3.2 & 3.0 & 1.1 & 2.6 & 3.0 & 15.3 & 3.8 \\
\hline $\mathrm{Sr}$ & 240 & 222 & 289 & 161 & 607 & 544 & 566 & 404 & 1484 & 610 & 823 & 184 & 29 & 11 & 176 \\
\hline Та & 0.36 & 0.35 & 0.35 & 0.63 & 0.02 & 0.05 & 0.02 & 0.11 & 0.81 & 0.51 & 0.20 & 0.80 & 0.68 & 2.32 & 1.04 \\
\hline Th & 2.01 & 1.96 & 1.87 & 3.18 & 0.17 & 0.36 & 0.14 & 0.78 & 18.78 & 2.73 & 4.48 & 5.04 & 5.64 & 13.97 & 7.28 \\
\hline$U$ & 1.01 & 0.77 & 0.62 & 1.22 & 0.06 & 4.91 & 0.06 & 0.18 & 3.96 & 0.86 & 1.38 & 1.35 & 1.38 & 2.83 & 1.52 \\
\hline V & 280 & 240 & 289 & 71 & 45 & 102 & 50 & 172 & 207 & 181 & 184 & 14 & 2 & 1 & 14 \\
\hline W & 0.42 & 0.60 & $<$ D.L. & 0.74 & < D.L. & 0.33 & < D.L. & $<$ D.L. & 0.33 & $<$ D.L. & $<$ D.L. & $<$ D.L. & $<$ D.L. & 0.94 & 0.22 \\
\hline Y & 44.5 & 40.0 & 45.0 & 58.4 & 4.0 & 7.2 & 3.6 & 14.8 & 25.8 & 39.7 & 16.3 & 43.1 & 46.3 & 119.1 & 55.6 \\
\hline $\mathrm{Zn}$ & 130 & 126 & 131 & 161 & 20 & 35 & 39 & 68 & 171 & 115 & 105 & 70 & 76 & 314 & 66 \\
\hline $\mathrm{Zr}$ & 182 & 184 & 190 & 467 & 14 & 25 & 9 & 68 & 406 & 192 & 136 & 289 & 416 & 755 & 240 \\
\hline La & 13.2 & 14.5 & 12.5 & 22.3 & 1.8 & 2.8 & 1.4 & 4.8 & 139.0 & 40.1 & 22.6 & 32.7 & 32.2 & 63.0 & 26.4 \\
\hline $\mathrm{Ce}$ & 33.1 & 33.4 & 30.2 & 55.5 & 3.9 & 6.4 & 3.0 & 11.4 & 307.7 & 98.9 & 47.3 & 76.4 & 74.5 & 153.7 & 70.4 \\
\hline $\mathrm{Pr}$ & 4.96 & 4.95 & 4.92 & 8.38 & 0.55 & 0.92 & 0.42 & 1.64 & 38.00 & 13.80 & 6.28 & 10.14 & 9.78 & 20.86 & 10.27 \\
\hline $\mathrm{Nd}$ & 23.86 & 23.28 & 23.66 & 39.40 & 2.57 & 4.31 & 1.97 & 7.64 & 141.20 & 60.51 & 26.73 & 41.52 & 40.09 & 87.48 & 43.52 \\
\hline $\mathrm{Sm}$ & 6.73 & 6.48 & 6.94 & 10.52 & 0.69 & 1.13 & 0.56 & 2.17 & 21.76 & 12.24 & 5.32 & 8.70 & 8.62 & 20.87 & 10.15 \\
\hline Eu & 2.34 & 2.21 & 2.41 & 3.24 & 0.44 & 0.60 & 0.43 & 0.92 & 5.14 & 3.70 & 1.77 & 1.90 & 1.06 & 3.03 & 2.00 \\
\hline $\mathrm{Gd}$ & 7.91 & 7.43 & 8.10 & 11.16 & 0.76 & 1.29 & 0.63 & 2.41 & 11.94 & 9.86 & 4.26 & 7.43 & 8.07 & 20.33 & 9.20 \\
\hline $\mathrm{Tb}$ & 1.25 & 1.19 & 1.31 & 1.67 & 0.12 & 0.21 & 0.11 & 0.41 & 1.39 & 1.35 & 0.57 & 1.19 & 1.33 & 3.37 & 1.50 \\
\hline Dy & 7.89 & 7.15 & 8.01 & 10.14 & 0.75 & 1.28 & 0.67 & 2.51 & 6.12 & 7.67 & 3.14 & 7.32 & 8.15 & 20.63 & 9.29 \\
\hline $\mathrm{Ho}$ & 1.55 & 1.42 & 1.60 & 2.02 & 0.15 & 0.26 & 0.13 & 0.51 & 0.90 & 1.42 & 0.57 & 1.44 & 1.62 & 4.18 & 1.86 \\
\hline $\mathrm{Er}$ & 4.41 & 3.91 & 4.47 & 5.70 & 0.40 & 0.70 & 0.36 & 1.42 & 2.21 & 3.82 & 1.52 & 4.25 & 4.74 & 12.27 & 5.36 \\
\hline $\mathrm{Tm}$ & 0.65 & 0.55 & 0.65 & 0.83 & 0.06 & 0.11 & 0.05 & 0.21 & 0.29 & 0.54 & 0.22 & 0.67 & 0.74 & 1.95 & 0.83 \\
\hline $\mathrm{Yb}$ & 4.23 & 3.73 & 4.29 & 5.71 & 0.38 & 0.67 & 0.34 & 1.41 & 1.74 & 3.50 & 1.37 & 4.61 & 5.16 & 14.02 & 5.49 \\
\hline Lu & 0.64 & 0.57 & 0.65 & 0.91 & 0.06 & 0.10 & 0.05 & 0.21 & 0.25 & 0.53 & 0.21 & 0.72 & 0.84 & 2.24 & 0.82 \\
\hline ¿REE & 112.8 & 110.8 & 109.6 & 177.4 & 12.6 & 20.8 & 10.1 & 37.6 & 677.6 & 258.0 & 121.8 & 199.0 & 196.9 & 427.9 & 197.1 \\
\hline Mg\# & 17 & 17 & 17 & 20 & 56 & 46 & 56 & 45 & 25 & 26 & 33 & 19 & 4 & 1 & 18 \\
\hline $\mathrm{Ce} / \mathrm{Yb}$ & 8 & 9 & 7 & 10 & 10 & 10 & 9 & 8 & 176 & 28 & 35 & 17 & 14 & 11 & 13 \\
\hline $\mathrm{La}_{N} / \mathrm{Nb}_{\mathrm{N}}$ & 3.4 & 3.7 & 3.2 & 2.9 & 6.9 & 4.1 & 7.5 & 3.5 & 10.1 & 7.0 & 9.8 & 3.5 & 4.3 & 2.3 & 2.6 \\
\hline
\end{tabular}




\begin{tabular}{|c|c|c|c|c|c|c|c|c|c|c|c|c|c|c|c|}
\hline Sample & SP10 & SP16B & SP18 & S20 & S1 & CS48A & S2 & S5 & SP15A & CS14A & CS18A & SP3 & SP8B & CS45B & CS1A \\
\hline Location & Haggier & Haggier & Haggier & $\begin{array}{l}\text { Haggier } \\
\text { Basaltic }\end{array}$ & Haggier & Haggier & $\begin{array}{l}\text { Haggier } \\
\text { Gabbro }\end{array}$ & $\begin{array}{l}\text { Haggier } \\
\text { Gabbro }\end{array}$ & $\begin{array}{l}\text { Haggier } \\
\text { Altered }\end{array}$ & Qalansya & Qalansya & Haggier & Haggier & Haggier & Haggier \\
\hline Litionigy & IVialic uike & Midic tuin & Midilic Gike & lava & Cuminale & cumulate & & & basalt & Diorites & Diorites & Bt Granite & Bt Granite & Bt Granite & Bt Granite \\
\hline \multicolumn{16}{|l|}{$\%$} \\
\hline $\mathrm{SiO} 2$ & 48.92 & 55.04 & 51.82 & 59.86 & 48.09 & 50.94 & 49.63 & 51.10 & 49.11 & 49.38 & 54.55 & 71.67 & 75.11 & 73.68 & 72.45 \\
\hline $\mathrm{Al} 2 \mathrm{O} 3$ & 14.31 & 13.52 & 14.60 & 10.64 & 26.32 & 23.26 & 21.08 & 17.30 & 15.31 & 16.94 & 17.21 & 13.89 & 12.88 & 11.72 & 14.34 \\
\hline $\mathrm{Fe} 2 \mathrm{O} 3 \mathrm{t}$ & 13.03 & 11.59 & 13.99 & 11.21 & 2.71 & 4.10 & 5.53 & 7.80 & 8.86 & 11.15 & 8.48 & 2.15 & 1.99 & 3.47 & 1.90 \\
\hline $\mathrm{MnO}$ & 0.32 & 0.26 & 0.25 & 0.24 & 0.04 & 0.06 & 0.08 & 0.13 & 0.13 & 0.20 & 0.13 & 0.11 & 0.07 & 0.07 & 0.08 \\
\hline $\mathrm{MgO}$ & 2.86 & 2.43 & 3.07 & 2.89 & 3.70 & 3.66 & 7.55 & 6.72 & 3.15 & 4.08 & 4.40 & 0.53 & 0.08 & 0.05 & 0.43 \\
\hline $\mathrm{CaO}$ & 8.33 & 6.42 & 6.69 & 5.20 & 14.78 & 12.78 & 11.95 & 10.68 & 6.01 & 6.92 & 7.33 & 1.27 & 0.34 & 0.29 & 1.42 \\
\hline $\mathrm{Na} 2 \mathrm{O}$ & 3.61 & 4.06 & 3.86 & 2.66 & 2.13 & 2.70 & 2.81 & 3.02 & 4.05 & 4.48 & 4.36 & 5.04 & 5.25 & 4.31 & 5.14 \\
\hline K2O & 0.98 & 0.91 & 0.82 & 0.37 & 0.17 & 0.55 & 0.17 & 0.45 & 3.68 & 1.68 & 1.35 & 3.03 & 3.31 & 4.43 & 3.20 \\
\hline TiO2 & 2.33 & 2.15 & 2.52 & 1.86 & 0.20 & 0.51 & 0.18 & 0.90 & 2.46 & 1.76 & 1.45 & 0.37 & 0.16 & 0.25 & 0.36 \\
\hline P2O5 & 0.37 & 0.33 & 0.36 & 0.86 & $<$ D.L. & $<$ D.L. & < D.L. & 0.10 & 1.37 & 0.66 & 0.32 & 0.10 & 0.06 & $<$ D.L. & 0.07 \\
\hline LOI & 3.76 & 3.17 & 1.37 & 3.40 & 1.20 & 1.55 & 1.44 & 1.37 & 5.99 & 2.01 & 0.98 & 0.67 & 0.29 & 0.41 & 0.66 \\
\hline Total & 98.82 & 99.88 & 99.35 & 99.18 & 99.34 & 100.11 & 100.41 & 99.57 & 100.13 & 99.26 & 100.55 & 98.83 & 99.55 & 98.68 & 100.03 \\
\hline \multicolumn{16}{|l|}{ ppm } \\
\hline As & 3 & 3 & 4 & 2 & $<$ D.L. & $<$ D.L. & $<$ D.L. & $<$ D.L. & 4 & $<$ D.L. & $<$ D.L. & $<$ D.L. & $<$ D.L. & 2 & $<$ D.L. \\
\hline $\mathrm{Ba}$ & 210 & 225 & 224 & 76 & 77 & 133 & 85 & 142 & 1338 & 670 & 669 & 821 & 816 & 307 & 744 \\
\hline $\mathrm{Be}$ & 1.4 & < D.L. & $<$ D.L. & 2.6 & < D.L. & $<$ D.L. & $<$ D.L. & 0.5 & 2.7 & 1.4 & 1.0 & 2.3 & 2.3 & 8.1 & 2.3 \\
\hline $\mathrm{Bi}$ & $<$ D.L. & $<$ D.L. & $<$ D.L. & < D.L. & $<$ D.L. & $<$ D.L. & $<$ D.L. & $<$ D.L. & $<$ D.L. & $<$ D.L. & $<$ D.L. & $<$ D.L. & $<$ D.L. & 0.4 & $<$ D.L. \\
\hline $\mathrm{Cd}$ & 0.3 & $<$ D.L. & 0.2 & 0.2 & $<$ D.L. & 0.1 & 0.1 & $<$ D.L. & 0.2 & $<$ D.L. & 0.2 & $<$ D.L. & 0.2 & 0.7 & $<$ D.L. \\
\hline Co & 27.7 & 23.5 & 28.5 & 16.4 & 15.0 & 18.2 & 40.5 & 38.1 & 21.3 & 24.7 & 25.2 & 1.5 & 0.7 & $<$ D.L. & 1.4 \\
\hline $\mathrm{Cr}$ & 18 & 15 & 18 & 0 & 211 & 88 & 165 & 123 & 27 & $<$ D.L. & 52 & 6 & 6 & 4 & 6 \\
\hline Cs & 1.9 & 4.0 & 0.8 & 0.3 & 0.3 & 1.0 & 0.4 & 1.5 & 2.6 & 0.5 & 0.6 & 1.0 & 0.7 & 1.1 & 1.3 \\
\hline $\mathrm{Cu}$ & 29 & 12 & 23 & 8 & 38 & 24 & 108 & 78 & 61 & 154 & 55 & $<$ D.L. & $<$ D.L. & 26 & 17 \\
\hline Ga & 20.4 & 19.4 & 24.1 & 23.2 & 18.5 & 18.5 & 16.6 & 18.5 & 25.8 & 20.4 & 20.6 & 21.1 & 22.2 & 31.9 & 20.3 \\
\hline $\mathrm{Ge}$ & 1.7 & 1.5 & 1.9 & 2.6 & 0.9 & 1.0 & 0.9 & 1.3 & 1.6 & 1.4 & 1.2 & 1.7 & 1.8 & 2.4 & 1.7 \\
\hline $\mathrm{Hf}$ & 4.99 & 4.88 & 4.97 & 9.65 & 0.36 & 0.72 & 0.28 & 1.64 & 8.77 & 4.49 & 3.21 & 7.47 & 10.35 & 21.28 & 6.29 \\
\hline In & 0.10 & < D.L. & 0.11 & < D.L. & $<$ D.L. & $<$ D.L. & $<$ D.L. & $<$ D.L. & $<$ D.L. & $<$ D.L. & $<$ D.L. & $<$ D.L. & 0.12 & 0.25 & $<$ D.L. \\
\hline Mo & 0.8 & 0.7 & 1.1 & 0.6 & 0.6 & 2.9 & 0.0 & 0.4 & 0.6 & 0.7 & 0.4 & 0.4 & 0.6 & 1.5 & 0.7 \\
\hline $\mathrm{Nb}$ & 4.0 & 4.0 & 4.0 & 7.7 & 0.3 & 0.7 & 0.2 & 1.4 & 14.0 & 5.8 & 2.3 & 9.5 & 7.5 & 27.6 & 10.3 \\
\hline $\mathrm{Ni}$ & 10 & 8 & 7 & < D.L. & 73 & 30 & 122 & 50 & 16 & $<$ D.L. & 35 & < D.L. & $<$ D.L. & $<$ D.L. & < D.L. \\
\hline $\mathrm{Pb}$ & 8 & 11 & 5 & 15 & 4 & 4 & 1 & 3 & 40 & 6 & 8 & 9 & 8 & 52 & 11 \\
\hline $\mathrm{Rb}$ & 22 & 19 & 16 & 5 & 3 & 13 & 2 & 10 & 47 & 40 & 21 & 56 & 55 & 104 & 66 \\
\hline $\mathrm{Sb}$ & 0.2 & 0.7 & 0.2 & 0.8 & $<$ D.L. & 0.1 & $<$ D.L. & $<$ D.L. & 0.4 & $<$ D.L. & $<$ D.L. & $<$ D.L. & $<$ D.L. & 0.5 & 0.1 \\
\hline Sn & 2.1 & 1.7 & 2.0 & 2.4 & $<$ D.L. & 1.0 & $<$ D.L. & 0.6 & 3.2 & 3.0 & 1.1 & 2.6 & 3.0 & 15.3 & 3.8 \\
\hline $\mathrm{Sr}$ & 240 & 222 & 289 & 161 & 607 & 544 & 566 & 404 & 1484 & 610 & 823 & 184 & 29 & 11 & 176 \\
\hline Та & 0.36 & 0.35 & 0.35 & 0.63 & 0.02 & 0.05 & 0.02 & 0.11 & 0.81 & 0.51 & 0.20 & 0.80 & 0.68 & 2.32 & 1.04 \\
\hline Th & 2.01 & 1.96 & 1.87 & 3.18 & 0.17 & 0.36 & 0.14 & 0.78 & 18.78 & 2.73 & 4.48 & 5.04 & 5.64 & 13.97 & 7.28 \\
\hline$U$ & 1.01 & 0.77 & 0.62 & 1.22 & 0.06 & 4.91 & 0.06 & 0.18 & 3.96 & 0.86 & 1.38 & 1.35 & 1.38 & 2.83 & 1.52 \\
\hline V & 280 & 240 & 289 & 71 & 45 & 102 & 50 & 172 & 207 & 181 & 184 & 14 & 2 & 1 & 14 \\
\hline W & 0.42 & 0.60 & $<$ D.L. & 0.74 & < D.L. & 0.33 & < D.L. & $<$ D.L. & 0.33 & $<$ D.L. & $<$ D.L. & $<$ D.L. & $<$ D.L. & 0.94 & 0.22 \\
\hline Y & 44.5 & 40.0 & 45.0 & 58.4 & 4.0 & 7.2 & 3.6 & 14.8 & 25.8 & 39.7 & 16.3 & 43.1 & 46.3 & 119.1 & 55.6 \\
\hline $\mathrm{Zn}$ & 130 & 126 & 131 & 161 & 20 & 35 & 39 & 68 & 171 & 115 & 105 & 70 & 76 & 314 & 66 \\
\hline $\mathrm{Zr}$ & 182 & 184 & 190 & 467 & 14 & 25 & 9 & 68 & 406 & 192 & 136 & 289 & 416 & 755 & 240 \\
\hline La & 13.2 & 14.5 & 12.5 & 22.3 & 1.8 & 2.8 & 1.4 & 4.8 & 139.0 & 40.1 & 22.6 & 32.7 & 32.2 & 63.0 & 26.4 \\
\hline $\mathrm{Ce}$ & 33.1 & 33.4 & 30.2 & 55.5 & 3.9 & 6.4 & 3.0 & 11.4 & 307.7 & 98.9 & 47.3 & 76.4 & 74.5 & 153.7 & 70.4 \\
\hline $\mathrm{Pr}$ & 4.96 & 4.95 & 4.92 & 8.38 & 0.55 & 0.92 & 0.42 & 1.64 & 38.00 & 13.80 & 6.28 & 10.14 & 9.78 & 20.86 & 10.27 \\
\hline $\mathrm{Nd}$ & 23.86 & 23.28 & 23.66 & 39.40 & 2.57 & 4.31 & 1.97 & 7.64 & 141.20 & 60.51 & 26.73 & 41.52 & 40.09 & 87.48 & 43.52 \\
\hline $\mathrm{Sm}$ & 6.73 & 6.48 & 6.94 & 10.52 & 0.69 & 1.13 & 0.56 & 2.17 & 21.76 & 12.24 & 5.32 & 8.70 & 8.62 & 20.87 & 10.15 \\
\hline Eu & 2.34 & 2.21 & 2.41 & 3.24 & 0.44 & 0.60 & 0.43 & 0.92 & 5.14 & 3.70 & 1.77 & 1.90 & 1.06 & 3.03 & 2.00 \\
\hline $\mathrm{Gd}$ & 7.91 & 7.43 & 8.10 & 11.16 & 0.76 & 1.29 & 0.63 & 2.41 & 11.94 & 9.86 & 4.26 & 7.43 & 8.07 & 20.33 & 9.20 \\
\hline $\mathrm{Tb}$ & 1.25 & 1.19 & 1.31 & 1.67 & 0.12 & 0.21 & 0.11 & 0.41 & 1.39 & 1.35 & 0.57 & 1.19 & 1.33 & 3.37 & 1.50 \\
\hline Dy & 7.89 & 7.15 & 8.01 & 10.14 & 0.75 & 1.28 & 0.67 & 2.51 & 6.12 & 7.67 & 3.14 & 7.32 & 8.15 & 20.63 & 9.29 \\
\hline $\mathrm{Ho}$ & 1.55 & 1.42 & 1.60 & 2.02 & 0.15 & 0.26 & 0.13 & 0.51 & 0.90 & 1.42 & 0.57 & 1.44 & 1.62 & 4.18 & 1.86 \\
\hline $\mathrm{Er}$ & 4.41 & 3.91 & 4.47 & 5.70 & 0.40 & 0.70 & 0.36 & 1.42 & 2.21 & 3.82 & 1.52 & 4.25 & 4.74 & 12.27 & 5.36 \\
\hline $\mathrm{Tm}$ & 0.65 & 0.55 & 0.65 & 0.83 & 0.06 & 0.11 & 0.05 & 0.21 & 0.29 & 0.54 & 0.22 & 0.67 & 0.74 & 1.95 & 0.83 \\
\hline $\mathrm{Yb}$ & 4.23 & 3.73 & 4.29 & 5.71 & 0.38 & 0.67 & 0.34 & 1.41 & 1.74 & 3.50 & 1.37 & 4.61 & 5.16 & 14.02 & 5.49 \\
\hline Lu & 0.64 & 0.57 & 0.65 & 0.91 & 0.06 & 0.10 & 0.05 & 0.21 & 0.25 & 0.53 & 0.21 & 0.72 & 0.84 & 2.24 & 0.82 \\
\hline ¿REE & 112.8 & 110.8 & 109.6 & 177.4 & 12.6 & 20.8 & 10.1 & 37.6 & 677.6 & 258.0 & 121.8 & 199.0 & 196.9 & 427.9 & 197.1 \\
\hline Mg\# & 17 & 17 & 17 & 20 & 56 & 46 & 56 & 45 & 25 & 26 & 33 & 19 & 4 & 1 & 18 \\
\hline $\mathrm{Ce} / \mathrm{Yb}$ & 8 & 9 & 7 & 10 & 10 & 10 & 9 & 8 & 176 & 28 & 35 & 17 & 14 & 11 & 13 \\
\hline $\mathrm{La}_{N} / \mathrm{Nb}_{\mathrm{N}}$ & 3.4 & 3.7 & 3.2 & 2.9 & 6.9 & 4.1 & 7.5 & 3.5 & 10.1 & 7.0 & 9.8 & 3.5 & 4.3 & 2.3 & 2.6 \\
\hline
\end{tabular}




\begin{tabular}{|c|c|c|c|c|c|c|c|c|c|c|c|c|c|c|c|c|c|c|}
\hline \multirow[b]{2}{*}{ Echantillon } & \multirow[b]{2}{*}{ Domain } & \multicolumn{4}{|c|}{ Contents (ppm) } & \multirow{2}{*}{$\frac{\text { Measured }}{{ }^{204} \mathrm{~Pb} /{ }^{206} \mathrm{~Pb}}$} & \multirow[t]{2}{*}{$\% \mathrm{Pbc}$} & \multicolumn{7}{|c|}{ Corrected ratios } & \multicolumn{4}{|l|}{ Ages (Ma) } \\
\hline & & $\mathrm{Pb}$ & U & Th & $\mathrm{Th} / \mathrm{U}$ & & & ${ }^{207} \mathrm{~Pb} /{ }^{206} \mathrm{~Pb}$ & $\pm \sigma$ & ${ }^{206} \mathrm{~Pb} /{ }^{238} \mathrm{U}$ & $\pm \sigma$ & ${ }^{207} \mathrm{~Pb} /{ }^{235} \mathrm{U}$ & $\pm \sigma$ & Err. Corr & ${ }^{206} \mathrm{~Pb} /{ }^{238} \mathrm{U}$ & $\pm \sigma^{2}$ & ${ }^{7} \mathrm{~Pb} /{ }^{235} \mathrm{U}$ & \pm 0 \\
\hline HAEU1-a & Core & 5 & 44 & 34 & 0.77 & 2.46E-04 & $0.23 \%$ & 0.0667 & 0.0204 & 0.1379 & 0.0022 & 1.2680 & 0.0329 & 0.62 & 833 & 13 & 831 & 15 \\
\hline HAEU1-a & $\operatorname{Rim}$ & 6 & 52 & 41 & 0.79 & 1.04E-04 & $0.00 \%$ & 0.0690 & 0.0171 & 0.1344 & 0.0032 & 1.2779 & 0.0378 & 0.82 & 813 & 18 & 836 & 17 \\
\hline HAEU1-b & Core & 47 & 394 & 416 & 1.06 & 1.70E-05 & $0.00 \%$ & 0.0655 & 0.0058 & 0.1388 & 0.0025 & 1.2534 & 0.0240 & 0.95 & 838 & 14 & 825 & 11 \\
\hline HAEU1-b & $\operatorname{Rim}$ & 52 & 452 & 432 & 0.95 & $3.28 \mathrm{E}-04$ & $0.54 \%$ & 0.0653 & 0.0156 & 0.1346 & 0.0030 & 1.2121 & 0.0326 & 0.82 & 814 & 17 & 806 & 15 \\
\hline HAEU1-C & Core & 18 & 159 & 145 & 0.92 & 6.67E-05 & $0.04 \%$ & 0.0666 & 0.0079 & 0.1311 & 0.0018 & 1.2038 & 0.0193 & 0.87 & 794 & 10 & 802 & 9 \\
\hline HAEU1-d & Core & 18 & 123 & 109 & 0.89 & $5.50 \mathrm{E}-05$ & $0.03 \%$ & 0.0663 & 0.0083 & 0.1686 & 0.0028 & 1.5412 & 0.0288 & 0.90 & 1005 & 16 & 947 & 11 \\
\hline HAEU1-d & $\operatorname{Rim}$ & 41 & 315 & 387 & 1.23 & 4.29E-05 & $0.04 \%$ & 0.0658 & 0.0081 & 0.1513 & 0.0028 & 1.3719 & 0.0274 & 0.91 & 908 & 15 & 877 & 12 \\
\hline HAEU1-e & Core & 25 & 177 & 233 & 1.32 & 3.05E-05 & $0.00 \%$ & 0.0671 & 0.0068 & 0.1672 & 0.0020 & 1.5474 & 0.0215 & 0.87 & 997 & 11 & 949 & 9 \\
\hline HAEU1-e & Rim & 44 & 407 & 673 & 1.65 & 1.97E-04 & $0.31 \%$ & 0.0675 & 0.0081 & 0.1251 & 0.0021 & 1.1645 & 0.0215 & 0.90 & 760 & 12 & 784 & 10 \\
\hline HAEU1-f & Rim & 17 & 175 & 199 & 1.14 & $1.39 \mathrm{E}-04$ & $0.15 \%$ & 0.0669 & 0.0123 & 0.1113 & 0.0017 & 1.0257 & 0.0204 & 0.79 & 680 & 10 & 717 & 10 \\
\hline HAEU1-f & Core & 27 & 222 & 274 & 1.23 & $1.29 \mathrm{E}-04$ & $0.17 \%$ & 0.0664 & 0.0097 & 0.1421 & 0.0020 & 1.3012 & 0.0226 & 0.83 & 856 & 12 & 846 & 10 \\
\hline HAEU2-a & Core & 17 & 146 & 85 & 0.58 & $1.53 \mathrm{E}-05$ & $0.00 \%$ & 0.0662 & 0.0054 & 0.1387 & 0.0027 & 1.2654 & 0.0257 & 0.96 & 837 & 15 & 830 & 11 \\
\hline HAEU2-a & $\operatorname{Rim}$ & 12 & 116 & 58 & 0.50 & 4.51E-05 & $0.03 \%$ & 0.0659 & 0.0060 & 0.1245 & 0.0019 & 1.1317 & 0.0187 & 0.93 & 756 & 11 & 769 & 9 \\
\hline HAEU2-b & Core & 14 & 133 & 75 & 0.56 & $1.03 \mathrm{E}-04$ & $0.13 \%$ & 0.0671 & 0.0138 & 0.1242 & 0.0030 & 1.1496 & 0.0323 & 0.87 & 755 & 17 & 777 & 15 \\
\hline HAEU2-b & $\operatorname{Rim}$ & 15 & 170 & 76 & 0.45 & 1.43E-04 & $0.20 \%$ & 0.0664 & 0.0097 & 0.1054 & 0.0027 & 0.9645 & 0.0266 & 0.94 & 646 & 16 & 686 & 14 \\
\hline HAEU2-c & Core & 11 & 103 & 48 & 0.47 & $2.22 \mathrm{E}-04$ & $0.32 \%$ & 0.0674 & 0.0184 & 0.1205 & 0.0026 & 1.1202 & 0.0318 & 0.76 & 734 & 15 & 763 & 15 \\
\hline HAEU2-d & Core & 10 & 80 & 40 & 0.50 & $9.80 \mathrm{E}-05$ & $0.09 \%$ & 0.0675 & 0.0099 & 0.1427 & 0.0023 & 1.3284 & 0.0252 & 0.85 & 860 & 13 & 858 & 11 \\
\hline HAEU2-d & $\operatorname{Rim}$ & 13 & 112 & 58 & 0.51 & $6.50 \mathrm{E}-05$ & $0.05 \%$ & 0.0663 & 0.0079 & 0.1394 & 0.0038 & 1.2744 & 0.0363 & 0.96 & 841 & 22 & 834 & 16 \\
\hline HAEU2-e & Core & 13 & 115 & 61 & 0.53 & $1.10 \mathrm{E}-04$ & $0.13 \%$ & 0.0664 & 0.0083 & 0.1309 & 0.0027 & 1.1981 & 0.0268 & 0.93 & 793 & 15 & 800 & 12 \\
\hline HAEU2-e & Rim & 13 & 120 & 61 & 0.51 & $9.22 \mathrm{E}-05$ & $0.09 \%$ & 0.0667 & 0.0083 & 0.1299 & 0.0022 & 1.1948 & 0.0222 & 0.90 & 787 & 12 & 798 & 10 \\
\hline HAEU2-f & Core & 16 & 145 & 88 & 0.61 & $1.63 \mathrm{E}-04$ & $0.24 \%$ & 0.0664 & 0.0092 & 0.1268 & 0.0022 & 1.1604 & 0.0227 & 0.88 & 769 & 12 & 782 & 11 \\
\hline HAEU2-f & $\operatorname{Rim}$ & 18 & 169 & 101 & 0.59 & 2.66E-04 & $0.42 \%$ & 0.0669 & 0.0083 & 0.1218 & 0.0023 & 1.1236 & 0.0231 & 0.91 & 741 & 13 & 765 & 11 \\
\hline SHEU1-a & Rim & 24 & 217 & 252 & 1.16 & $8.90 \mathrm{E}-06$ & $0.00 \%$ & 0.0660 & 0.0051 & 0.1280 & 0.0025 & 1.1644 & 0.0236 & 0.97 & 776 & 14 & 784 & 11 \\
\hline SHEU1-b & $\operatorname{Rim}$ & 8 & 68 & 16 & 0.23 & $1.41 \mathrm{E}-04$ & $0.15 \%$ & 0.0660 & 0.0098 & 0.1312 & 0.0021 & 1.1940 & 0.0222 & 0.85 & 795 & 12 & 798 & 10 \\
\hline SHEU1-d & Core & 9 & 88 & 67 & 0.77 & 8.26E-06 & $0.00 \%$ & 0.0674 & 0.0048 & 0.1215 & 0.0017 & 1.1293 & 0.0170 & 0.95 & 739 & 10 & 767 & 8 \\
\hline SHEU1-d & Rim & 15 & 134 & 110 & 0.82 & $6.13 \mathrm{E}-06$ & $0.00 \%$ & 0.0666 & 0.0067 & 0.1295 & 0.0019 & 1.1885 & 0.0189 & 0.91 & 785 & 11 & 795 & 9 \\
\hline SHEU1-e & Core & 11 & 108 & 118 & 1.09 & $5.02 \mathrm{E}-04$ & $0.80 \%$ & 0.0641 & 0.0298 & 0.1233 & 0.0028 & 1.0909 & 0.0406 & 0.60 & 750 & 16 & 749 & 20 \\
\hline SHEU1-e & $\operatorname{Rim}$ & 15 & 141 & 137 & 0.97 & $5.68 \mathrm{E}-04$ & $0.92 \%$ & 0.0650 & 0.0573 & 0.1277 & 0.0022 & 1.1448 & 0.0685 & 0.29 & 775 & 13 & 775 & 32 \\
\hline SHEU1-f & Core & 12 & 101 & 89 & 0.87 & 1.06E-05 & $0.00 \%$ & 0.0668 & 0.0093 & 0.1336 & 0.0024 & 1.2314 & 0.0245 & 0.88 & 809 & 13 & 815 & 11 \\
\hline SHEU1-f & $\operatorname{Rim}$ & 13 & 97 & 83 & 0.86 & 5.07E-06 & $0.00 \%$ & 0.0681 & 0.0176 & 0.1596 & 0.0056 & 1.4971 & 0.0591 & 0.90 & 954 & 31 & 929 & 24 \\
\hline
\end{tabular}

